\title{
Acquired phototrophy in aquatic protists
}

\author{
Diane K. Stoecker ${ }^{1, *}$, Matthew D. Johnson ${ }^{2}$, Colomban de Vargas ${ }^{3}$, Fabrice Not $^{3}$ \\ ${ }^{1}$ University of Maryland Center for Environmental Science, Horn Point Laboratory, PO Box 775, \\ 2020 Horns Point Rd, Cambridge, Maryland 21613, USA \\ ${ }^{2}$ Woods Hole Oceanographic Institution, Watson Building 109, MS\#52, Woods Hole, Massachusetts 02543, USA \\ ${ }^{3}$ Evolution du Plancton et PaleOceans (EPPO) Lab., UMR 7144 - CNRS \& Univ. Paris VI, \\ Station Biologique de Roscoff - SBR, Place George Teissier, BP 74, 29682 Roscoff, Cedex, France
}

\begin{abstract}
Acquisition of phototrophy is widely distributed in the eukaryotic tree of life and can involve algal endosymbiosis or plastid retention from green or red origins. Species with acquired phototrophy are important components of diversity in aquatic ecosystems, but there are major differences in host and algal taxa involved and in niches of protists with acquired phototrophy in marine and freshwater ecosystems. Organisms that carry out acquired phototrophy are usually mixotrophs, but the degree to which they depend on phototrophy is variable. Evidence suggests that 'excess carbon' provided by acquired phototrophy has been important in supporting major evolutionary innovations that are crucial to the current ecological roles of these protists in aquatic ecosystems. Acquired phototrophy occurs primarily among radiolaria, foraminifera, ciliates and dinoflagellates, but is most ecologically important among the first three. Acquired phototrophy in foraminifera and radiolaria is crucial to their contributions to carbonate, silicate, strontium, and carbon flux in subtropical and tropical oceans. Planktonic ciliates with algal kleptoplastids are important in marine and fresh waters, whereas ciliates with green algal endosymbionts are mostly important in freshwaters. The phototrophic ciliate Myrionecta rubra can be a major primary producer in coastal ecosystems. Our knowledge of how acquired phototrophy influences trophic dynamics and biogeochemical cycles is rudimentary; we need to go beyond traditional concepts of 'plant' and 'animal' functions to progress in our understanding of aquatic microbial ecology. This is a rich area for exploration using a combination of classical and molecular techniques, laboratory and field research, and physiological and ecosystem modeling.
\end{abstract}

KEY WORDS: Mixotrophy · Radiolaria · Foraminifera - Ciliates · Dinoflagellates · Kleptoplastidy · Karyoklepty $\cdot$ Endosymbiosis $\cdot$ Myrionecta rubra

Resale or republication not permitted without written consent of the publisher

\section{INTRODUCTION}

Acquisition of phototrophy through maintenance of algal endosymbionts or algal organelles is common among aquatic phagotrophic protists. Most protists with acquired phototrophy are mixotrophic; they combine heterotrophy and phototrophy. Evolutionary biologists recognize algal endosymbiosis as one of the major mechanisms of eukaryotic evolution and as a driving force partially responsible for the great diversity of protists in aquatic environments (Lane \& Archibald 2008, Keeling 2009). The importance of acquired phototrophy is less recognized in aquatic microbial ecology.
Despite the information available on algal endosymbiosis (defined here as an intracellular association between a non-photosythetic host and a potentially autonomous eukaryote alga) and organelle retention (defined here as the retention of plastids and sometimes other organelles through feeding on algal prey) in particular protist groups (Anderson 1983a, Lee \& McEnery 1983, Dolan \& Perez 2000, Stoecker 1999), there is little quantitative information on the occurrence and importance of acquired phototrophy across taxa in aquatic ecosystems. Thus, this review has 3 main aims: (1) to summarize information on acquired phototrophy among 4 major groups of aquatic protests - the Foram- 
inifera, Radiolaria, Ciliophora and Dinozoa; (2) to categorize a bewildering array of relationships between protistan hosts and their algal endosymbionts or retained algal organelles so that their evolutionary significance and physiological and ecological roles can be appreciated; and (3) to summarize and synthesize information on the occurrence, abundance and biomass of protists with acquired phototrophy and their contributions to primary and secondary production and biogeochemical processes.

We hope this review will lead to increased elucidation and quantification of acquired phototrophy in aquatic protists, a greater recognition of its role in structuring trophic interactions, and a better appreciation of the contributions of mixotrophs and autotrophs with acquired phototrophy to aquatic ecology. Most ecological and biogeochemical models of aquatic ecosystems apply the traditional 'plant-animal' dichotomy which does not recognize the effects that acquired phototrophy may have on exchange between model compartments. Acquired phototrophy is a 'fact of life' in the euphotic zone of aquatic ecosystems; understanding it is important in predicting how aquatic ecosystems respond on evolutionary and ecological time scales to changing environments.

\section{ACQUIRED PHOTOTROPHY IN THE TREE OF LIFE}

The largest research effort and scientific literature on eukaryotic acquired phototrophy concerns the antique side of the process: the obligatory endosymbioses which led to massive gene loss/transfer from the endosymbiont and its transformation into an organelle. The origin, timing, and number of secondary and tertiary endosymbiotic events in the tree of eukaryotic life (Fig. 1) is a subject of intense and often largely speculative debate (Lane \& Archibald 2008, Sanchez-Puerta \& Delwiche 2008). Major constraints that hinder our current understanding of the evolution of phototrophy in eukaryotes are that (1) most of the events leading to permanent plastids in eukaryotes occurred at the dawn

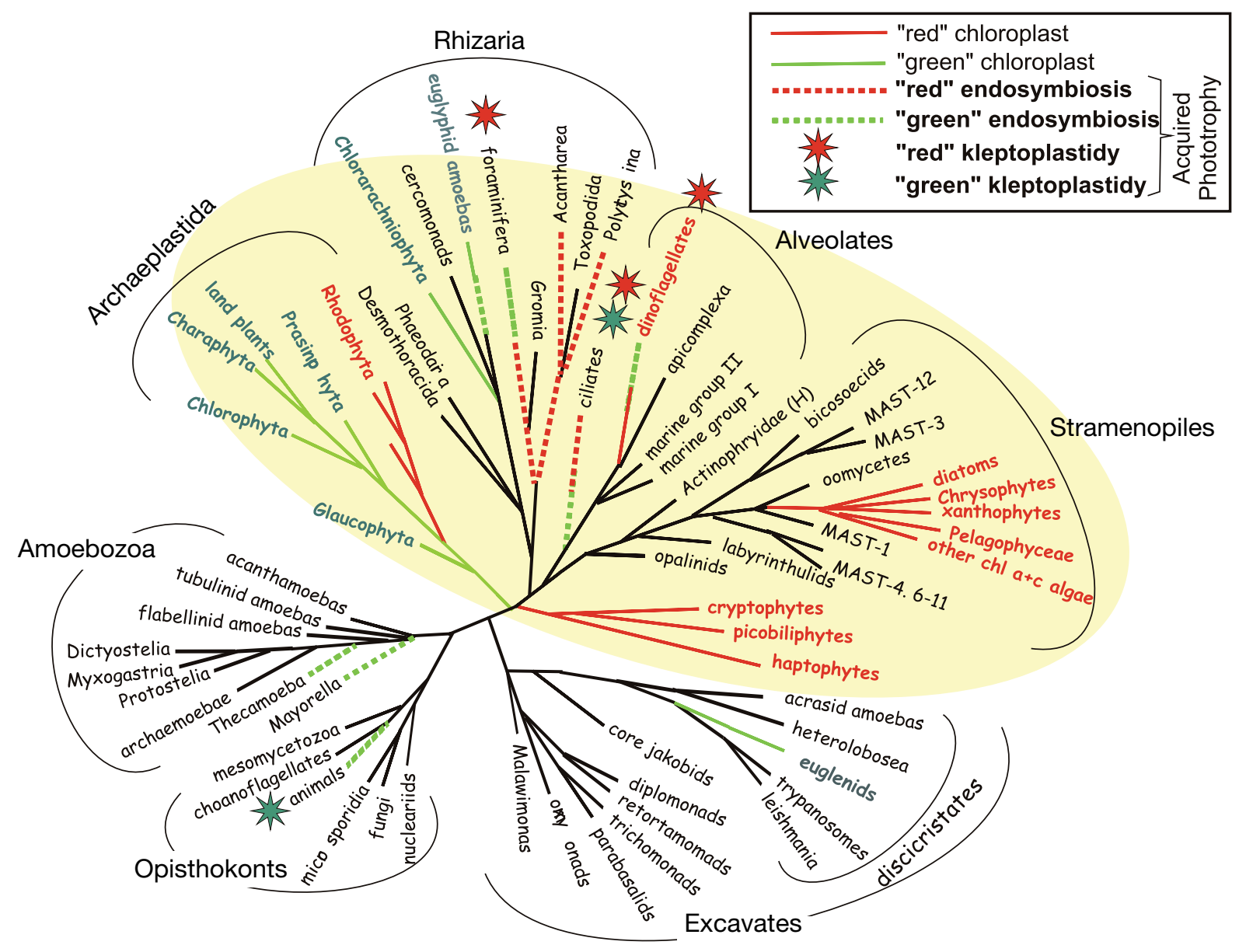

Fig. 1. Synthetic tree of eukaryotic life based on recent phylogenetic/genomic data (modified from Fehling et al. 2007). Acquired endosymbiosis and organelle retention based on both red and green plastids are concentrated in a mega-division including all permanent phototrophic protists plus pseudo-heterotrophic lineages 
of their evolutionary history, many hundreds of million years ago, (2) both mixo- and heterotrophic protist lineages may have witnessed successive lateral gene transfers from their microalgal prey, adding a level of genomic complexity in addition to the classical constraints for reconstructing deep molecular phylogenies, and (3) entirely sequenced protistan genomes are still very scarce, and they typically include only 1 or 2 representatives of major lineages containing thousands or hundreds of thousands of species with various trophic status.

The tree of eukaryotic life has evolved as a function of the availability of novel genomic data. Among the recent exciting results based on multi-gene phylogenies (Hackett et al. 2003, Burki et al. 2008) is the emergence of a super-group that contains all permanent phototrophic eukaryotes (with the exception of euglenoids) resulting from primary, secondary, and tertiary endosymbioses (Burki et al. 2008) together with the 'heterotrophic' groups discussed in this review (Rhizaria, ciliates, dinoflagellates, katablepharids). Thus, the latest version of the tree of eukaryotic life divides along a primary phototrophy versus heterotrophy dichotomy, whose origin (the primary endosymbiosis between a cyanobacteria and an ancestral eukaryote) may have occurred even before the split between the 'green' (Archaeplastida) and the 'red' (Chromista + Rhizaria) protistan lineages. In such cases, the secondary endosymbiotic event(s) leading to the chlorophyll (chl) $a+c$ microalgae would in fact correspond to proterozoic processes of plastid replacement. In any case, it appears that a photosynthetic capacitation impacted a major and monophyletic part of the tree of eukaryotic life very early on (yellow in Fig. 1), so that the groups of heterotrophic protists in this half of the tree would have an enhanced ability for acquired phototrophy. They may systematically come from lineages that lost their plastid early in the radiation of photosynthetic protists, and have subsequently kept a genomic memory for plastid maintenance or oxygenic photosynthesis. Interestingly, this putative ancestral capacitation left flexibility in endosymbiosis and kleptoplastidy for both 'green' and 'red' symbionts/plastids in modern rhizarian and chromistan protists (Fig. 1).

\section{AN EVOLUTIONARY AND ECOLOGICAL SPECTRUM OF ACQUIRED PHOTOTROPHY IN PROTISTS}

Jones (1994) presented mixotrophy in aquatic microbial foodwebs as a spectrum of nutritional strategies between absolute heterotrophy and autotrophy. Here we have focused on this analogy relating it to one form of mixotrophy, acquired phototrophy (endosymbiosis and organelle retention), in an effort to categorize common trophic and evolutionary patterns among protists (Fig. 2). The simplest form of acquired phototrophy involves a transient and facultative association between host and symbiont, or prey organelles and predator. Distinguishing between transient and persistent-facultative acquired phototrophic associations is difficult in many cases, due to the lack of autecological information on most mixotrophic protists.

In protists with transient facultative acquired phototrophy, the cell will not require such an association for its survival, and in fact the association may not always be readily observed, but when present allows the host to grow faster. Transient facultative relationships in acquired phototrophy appear to be rare and are perhaps opportunistic in nature, involving the least amount of host or predator adaptation. The aplastidic dinoflagellate Pfiesteria piscicida is one such example, carrying out mixotrophy through organelle retention when fed cryptophyte algae (Lewitus et al. 1999). Retention time of plastids in $P$. piscicida is relatively brief in moderate light, lasting 1 to $2 \mathrm{~d}$ (Feinstein et al. 2002). $P$. piscicida is an extremely versatile predator, capable of ingesting diverse protistan prey under certain situations, and may even 'micro-predate' fish (Vogelbein et al. 2002).

Here we define persistent facultative relationships as cases where the host is almost always reported with acquired phototrophy, but where survival is not dependent upon symbionts or sequestered plastids. Generally, facultative associations do not involve extensive cytological or metabolic adaptation of the host or predator to accommodate foreign cells or plastids, respectively. Rather, the phenomenon enhances flexibility of nutritional sources with minimal energetic or coevolutionary investment in upkeep. This argument may be understood in terms of an organism's increased hypothetical cost in becoming a phototroph and maintaining permanent photosynthetic machinery (Raven 1997). Thus, by employing acquired phototrophy, it invests little energy while acquiring free labile carbon (Putt 1990b)

An example of a persistent facultative acquired phototrophy is the dinoflagellate Gyrodinium gracilentum, which is able to grow heterotrophically on cryptophyte prey in the dark $\left(0.53 \mathrm{~d}^{-1}\right)$, but only reaches its maximum growth rate when exposed to sufficient light $\left(1.2 \mathrm{~d}^{-1}\right)$ through kleptoplasty (Jakobsen et al. 2000). Even in this facultative relationship there appears to be some adaptation to prey selectivity and requirements for growth, as the dinoflagellate appears to only grow when fed cryptophyte algae (Jakobsen et al. 2000). An analogous example of a persistent facultative endosymbiosis may be found in tropical members of the dinoflagellate Noctiluca scintillans and the 


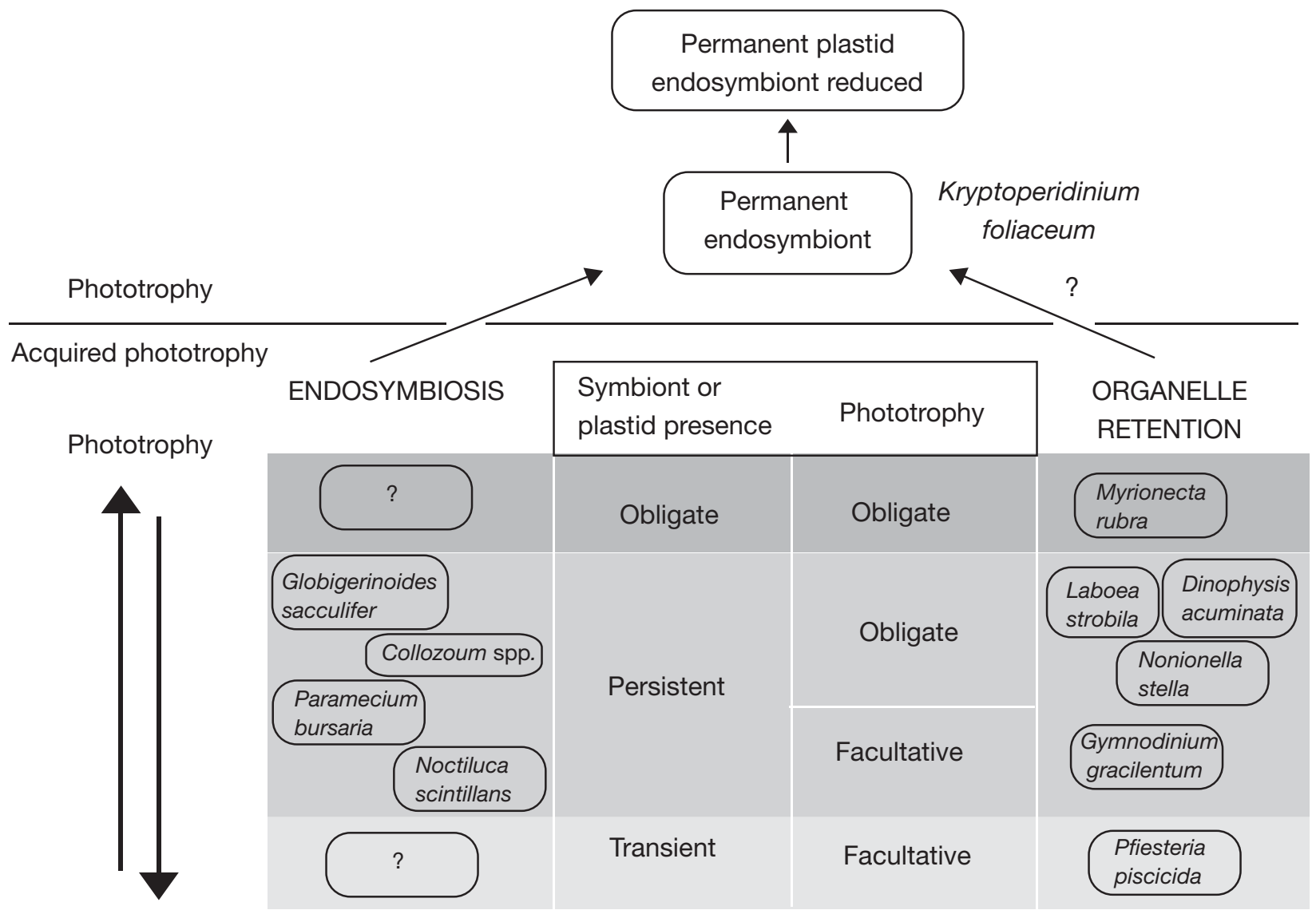

Heterotrophy

Fig. 2. An evolutionary and ecological spectrum of acquired phototrophy in protists; a conceptual gradient of acquired phototrophy between pure heterotrophy (bottom) and phototrophy (top), based on Jones' (1994) analysis of mixotrophy. The left side represents endosymbiosis in aquatic protists, while the right side represents organelle retention; the middle left column represents the degree to which a symbiont or plastid is present, while the right middle column indicates the role of acquired phototrophy in the host's metabolism. The top arrows represent a theoretical evolutionary acquisition of endosymbiont or foreign organelles, which may eventually result in a permanently integrated plastid. Examples of various protists that appear to fit into these categories are given

prasinophyte endosymbiont Pedinomonas noctilucae (Sweeney 1978). N. scintillans may possess within their large vacuolated cell thousands of free-swimming $P$. noctilucae, which provide most of the carbon requirements for their host to grow, despite its continued capacity to feed heterotrophically (Hansen et al. 2004). In the laboratory, however, $N$. scintillans loses its symbionts within $3 \mathrm{wk}$ of collection, and then grows as a functional heterotroph (Hansen et al. 2004). Thus, in N. scintillans, mixotrophy affords nutritional flexibility, allowing cells to survive in prey-impoverished oligotrophic tropical waters. The freshwater ciliate Paramecium bursaria harbors numerous endosymbiotic algae (Chlorella spp.); however, prolonged exposure to darkness results in asymbiotic cells that are able to grow heterotrophically (Karakashian 1963). Interestingly, while selective pressure on symbiotic strains of Chlorella has apparently made them genetically dis- tinct from free-living strains (Summerer et al. 2008), Paramecium has retained sufficient nutritional flexibility to survive as a heterotroph (Tonooka \& Watanabe 2002).

In persistent obligatory acquired phototrophy, an endosymbiont or plastid is nearly always present and the host does not grow without it. This is the most common type of acquired phototrophy in marine protists. The marine oligotrich ciliate Laboea strobila is one such example, requiring light and algal prey for growth and surviving longer during starvation in light than in darkness (Stoecker et al. 1988). Certain benthic foraminifera (Lopez 1979) may also fall into this category, although few laboratory studies are available to determine the precise role of sequestered plastids in their physiology. In the planktonic foraminifera Globigerinoides sacculifer, loss of dinoflagellate endosymbionts reduces survival time, induces gametogenesis, 
and results in smaller shell size compared to cells with symbionts (Bé et al. 1982, Caron et al. 1982). Persistent obligatory endosymbiotic relationships between freshwater or marine ciliates and Chlorella spp. or Symbiodinium, respectively, may also occur; however, few laboratory data are available to support these conclusions.

The most evolutionarily advanced form of acquired phototrophy involves obligate-obligate relationships, where the symbiont or sequestered organelles are always present, more or less stable (the host has some regulatory control), and removal of these symbionts or organelles from the host, results in its rapid death. While no eukaryotic-endosymbiont containing protists fit this classification (an example of a non-protist host could be certain cnidarians), several organelleretaining protists appear to satisfy these hypothetical requirements. The marine ciliate Myrionecta rubra (=Mesodinim rubrum) has been reported to both possess a permanent endosymbiont (Hansen \& Fenchel 2006) and to have the capacity to sequester nuclei from its cryptophyte prey (a process known as karyoklepty), in order to maintain and divide its 'symbiotic' organelles (Johnson et al. 2007). It's likely that M. rubra represents a 'species complex', and that certain members have a permanently integrated 'endosymbiont' of cryptophyte origin, while others still require acquisition of cryptophyte nucleus. Other taxa that may also fit into this category include an unidentified marine dinoflagellate isolated from Antarctica (RS-Dino) (Gast et al. 2007) and the katablepharid flagellate Hatena sp. (Okamoto \& Inouye 2006).

\section{OVERALL DIVERSITY OF ACQUIRED PHOTOTROPHY FROM ENDOSYMBIONTS AND SEQUESTERED PLASTIDS}

The diversity of modern eukaryotic phytoplankton in today's oceans is dominated by algae with red plastids (major pigment chlorophyll $c$ ), including the dinoflagellates, diatoms, and coccolithophores, while freshwater and terrestrial environments continue to be dominated by green algae (major pigment chlorophyll b) (Falkowski et al. 2004). One major reason for this difference in evolutionary selection between environments is believed to be the dramatic rise in oxidation state of the surface ocean during the end of the Phanerozoic eon, making biologically available iron and manganese scarce in surface oceans, both of which are more abundant in cells of the green plastid lineage (Quigg et al. 2003). As expected, these patterns of plastid selection between fresh and marine habitats hold true for diversity of endosymbionts and sequestered plastids in acquired phototrophy. In all cases where the endosymbiont is identified in freshwater protists it belongs to the chlorophyte lineage (mostly Chlorella spp.), whereas only $12.5 \%$ of known marine endosymbiotic associations include a green lineage endosymbiont (Fig. 3A,B). While the amount of described diversity of red lineage sequestered plastids in freshwater protists is about twice that of the green, in about $66 \%$ of all cases the kleptoplast is undefined (Fig. 3D). The diversity and functional role of organelle retention in freshwater habitats appears to be one of the largest gaps in our knowledge of acquired phototrophy. In marine environments, where organelle retention has been studied in greater detail, half of all known examples of organelle retention involve a prey cell of red plastid origin, while only $11 \%$ are green (Fig. 3C). The red dominated disparity for marine endosymbiotic associations is even greater, with nearly $70 \%$ of all known symbiont-associated protists having a symbiont with red-lineage plastids (Fig. 3A). Most of these described marine endosymbionts are dinoflagellates. Pelagic foraminifera are known to house a diverse assemblage of dinoflagellate endosymbionts related to the Symbiodinium complex, better known for its associations with cnidarians (Pochon et al. 2006, Shaked \& de Vargas 2006), whereas endosymbionts of Radiolaria are associated with the dinoflagellate genus Scrippsiella. In comparison to the corals, a higher diversity of symbiotic dinoflagellates are observed in pelagic rhizaria, this may be a result of their complex alternation of generations life history, which requires their pelagic endosymbionts to maintain a partially free-living existence (Shaked \& de Vargas 2006).

Taxon diversity of sequestered plastids in marine environments appears to vary somewhat with host specificity and diversity. Planktonic oligotrich ciliates are perhaps the most generalist of all organelle sequestering protists, retaining plastids from nearly all of the chlorophyll $c$ containing algal groups, and a few chlorophyll $b$ containing algae, such as prasinophytes (Laval-Peuto \& Febvre 1986). In contrast, nearly all $(\sim 76 \%)$ organelle-retaining dinoflagellates sequester plastids from cryptomonad algae. The reason for this is unclear; however, some have speculated that the persistence of the nucleomorph (NM: a vestigial eukaryotic nucleus from a red-algal ancestor) and the periplastidal membrane (PM), which surrounds cryptomonad plastids and the NM, may aid in maintaining some plastid autonomy (Lewitus et al. 1999). However, an exception to this rule is the kleptoplastidic dinoflagellate Dinophysis, which sequesters its plastids from the photosynthetic ciliate Myrionecta rubra (Park et al. 2006). In D. fortii, the dinoflagellate siphons cellular contents from $M$. rubra by myzocytotic feeding, and reduces cryptophyte plastids to 

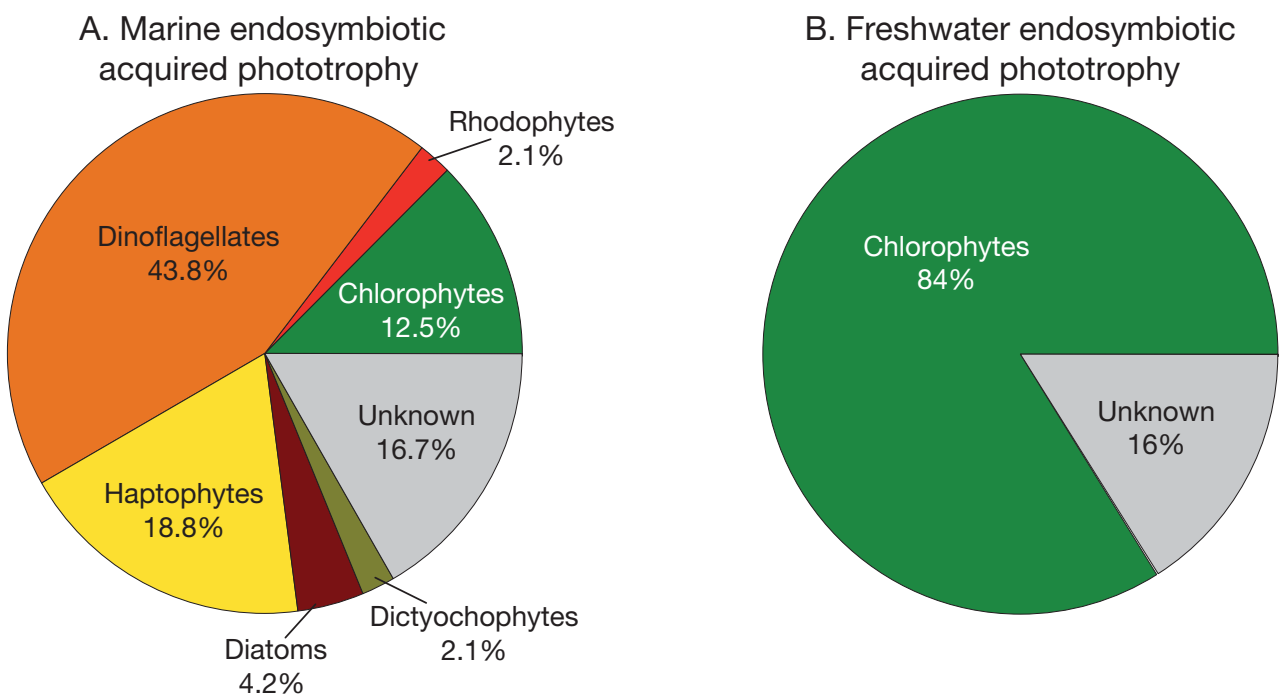

\section{Marine organelle-retention acquired phototrophy}

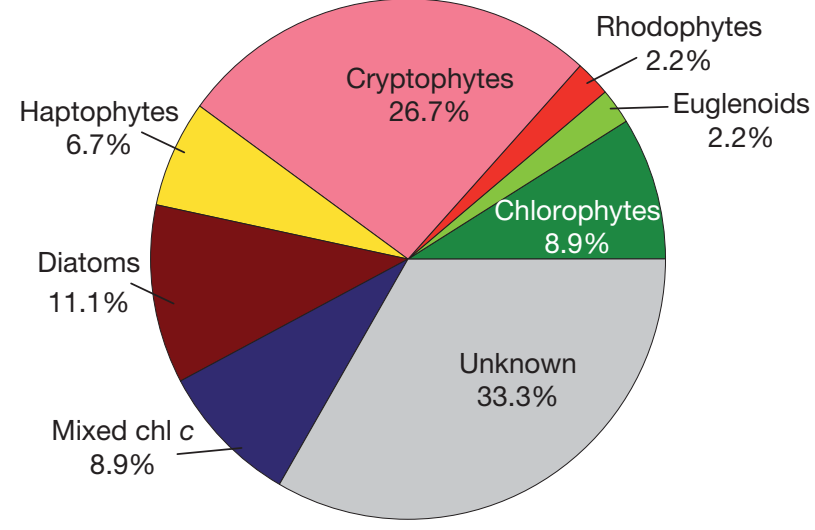
D. Freshwater organelle-retention acquired phototrophy

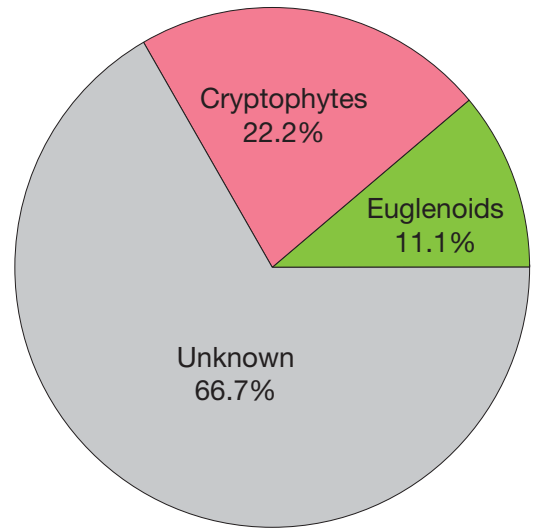

Fig. 3. Diversity of acquired phototrophy endosymbionts and sequestered plastids in marine and freshwater ecosystems. (A) Marine endosymbiotic acquired phototrophy; (B) freshwater endosymbiotic acquired phototrophy; (C) marine organelleretention acquired phototrophy; (D) freshwater organelle-retention acquired phototrophy. Numbers in each pie represent percentage of total acquired phototrophy interactions for the rhizaria (foraminifera, radiolaria), ciliates, and dinoflagellates combined

their double membranes, digesting away the PM and NM (Nagai et al. 2008). Thus far, nearly all sequestered cryptophyte plastids in marine protists have been shown to be from the Teleaulax/Geminigera clade of cryptophytes (Takishita et al. 2002, Hackett et al. 2003, Johnson et al. 2006, Minnhagen \& Janson 2006, Park et al. 2006, 2008, Koike \& Takishita 2008), while most freshwater cryptophyte kleptoplasts are usually Chroomonas spp. (Wilcox \& Wedemayer 1985, Fields \& Rhodes 1991). The dinoflagellates D. mitra (Koike et al. 2005) and an unidentified Ross Sea dinoflagellate (RS-Dino) (Gast et al. 2007) are exceptions to this trend of plastid selection, as they sequester organelles from prymnesiophyte algae rather than cryptomonads.
Previous studies have made linkages between plastid genome size and its evolutionary 'portability' in symbiotic associations (Grzebyk et al. 2003). However, with the exception of dinoflagellate minicircle genomes, differences in plastid genome content in red and green lineages pale in comparison to the thousands of nuclear-encoded, plastid-targeted genes that reside in all algal genomes (Martin \& Herrmann 1998). Thus, it is unclear as to how much plastid genome size influences the stability and function of kleptoplasts. Selection of kleptoplasts or symbionts by predators or hosts, respectively, may be driven in many cases by adaptation and selection of predator-prey dynamics, rather than optimal kleptoplast or symbiont performance per se. 


\section{OCCURRENCE AND FUNCTION OF ACQUIRED PHOTOTROPHY IN AQUATIC PROTISTS}

\section{Rhizaria}

Among the planktonic foraminifera, an estimated $25 \%$ of the 40 to 50 extant species are known to harbour algal symbionts (Hemleben et al. 1989). Caron et al. (1995) estimated that roughly half of foraminiferan species in surface waters of oceanic gyres possess symbiotic algae at some point of their life history. In the Equatorial Pacific $\left(140^{\circ} \mathrm{W}\right.$ equator) Stoecker et al. (1996) observed that over $80 \%$ of foraminifera were plastidic and contributed $\sim 70 \%$ of foraminifera biomass.

Algal symbionts of planktonic foraminifera belong to dinoflagellates and prymnesiophytes (see Table S1 available as supplementary material at www.int-res. com/articles/suppl/a057p279_app.pdf). Recent molecular investigations resulted in more accurate identification of foraminiferan algal endosymbionts. For instance, Globigerinella siphonifera symbionts were first described as chrysophytes based on ultrastructure images, but molecular evidence suggests that they actually belong to the prymnesiophytes and are closely related to the Prymnesium genus (Table S1) (Gast et al. 2000, Gast \& Caron 2001). Dinoflagellate symbionts of foraminifera are regarded as relatives to Symbiodinium of corals but form a separate and consistent clade close to the described species Gymnodinium beii (Shaked \& de Vargas 2006). Neither diatoms or green algal symbionts, nor plastid retention phenomena, have been reported in planktonic foraminifera.

It is currently assumed that all marine benthic larger foraminifera harbour algal symbionts or retain plastids and each host cell can bear hundreds of algal endosymbionts (Lee 1998, Lee 2006). Benthic foraminifera exhibit a great variety of symbionts, members of various families (Peneroplidae, Archaiasidae, Sortidae, Alveolinidae) are hosts of red, chlorophyte, dinoflagellate, and diatom endosymbionts, respectively (Pawlowski et al. 2001a, Lee 2006). Small pennate diatoms are the most common algal symbionts found in benthic foraminifera. In Caribbean waters $75 \%$ of the algal endosymbionts were identified as diatoms, with the genus Nitzschia isolated from more than $55 \%$ of the hosts (Lee et al. 1995). In addition to several Nitzschia species, diatoms from the genera Fragilaria and Navicula have also been regularly found as symbionts in benthic foraminifera (Lee 2006). Occasionally, more than one diatoms species can be isolated from the same host (Lee \& McEnery 1983, Lee 2006). Dinoflagellate symbionts of benthic foraminifera belong to the Symbiodinium species complex (Pawlowski et al. 2001b). They appear to be more closely related to the symbionts of benthic invertebrates than to the symbionts of the planktonic Foraminifera (Gymnodinium) (Gast \& Caron 1996). According to molecular investigations, the green symbionts of 5 genera in the Archaiasidae family all belong to distinct species within the Chlamydomonas genus. The species C. noctigama is thought to be the ancestor for this group of symbionts (Pawlowski et al. 2001a). The red alga Porhyridium purpurum has been isolated from the foraminiferan genus Peneroplis (Lee 1990, 2006) and the prymnesiophyte Pleurochrysis scherffelii has been reported as a symbiont in the species Marginopora vertebralis (Lee et al. 1997). Kleptoplastids of benthic foraminifera are all from diatoms (Table S1). Species of Elphidium have been shown to retain $\sim 3.7 \times 10^{4}$ plastids per cell. The plastids have half-lives of up to $9 \mathrm{wk}$ in starved hosts incubated in the dark (Correia \& Lee 2002). Plastids from diatoms are also retained in benthic bathyal foraminifera inhabiting extreme environments, such as cold seeps or anoxic waters, where no light is present. None of the freshwater foraminifera are reported to have algal endosymbionts or plastids (Holzmann et al. 2003).

Radiolaria (Acantharea and Polycystinea) are exclusively marine planktonic protists. No kleptoplastidy has been reported in these groups. It is assumed that nearly all Acantharea, except primitive forms in the Holacanthida (Tregouboff 1953, C. Febvre-Chevalier pers. comm.) bear algal endosymbionts at some point of their life history. However, because Acantharea lose their symbiotic algae before reproduction, large individuals can be aposymbiotic (Caron et al. 1995). Fields studies in the Equatorial Pacific and in the Gulf of Mexico observed that $\sim 40 \%$ of Acantharea had plastids and contributed to $\sim 80 \%$ of Acantharea biomass (Stoecker et al. 1996) and that $70 \%$ of Acantharea in the upper $50 \mathrm{~m}$ of the water column north of Puerto Rico had algal symbionts (Taylor 1982).

All Acantharea algal endosymbionts described so far have been identified as belonging to the prymnesiophytes (Febvre \& Febvre-Chevalier 1979, Gast et al. 2000) (Table S1). The average number of algal symbionts per cell is 15 (range 11 to 23) (Michaels 1988, 1991). The presence of dinoflagellate-related symbionts can not be ruled out in the Chaunacanthida group, but this has to be confirmed by molecular techniques (C. Febvre-Chevalier pers. comm.). Conclusions about endosymbiont specificity in many of the Acantharea are essentially based on electron microscopy images and require further investigation using culturing methods associated with molecular tools. Despite their relative abundance in surface waters of tropical seas and their significant contribution to biomass, very little information is available regarding the algal endosymbiont diversity of Acan- 
tharea. Moreover, because their strontium sulphate skeleton dissolves rapidly, there is no fossil record for Acantharea (Kunimoto et al. 2006) and this group has received much less attention than Polycystinea.

Polycystinea is a group composed of both colonial and solitary organisms. Colonial radiolarians occur predominantly in oligotrophic open oceans but can be found to a lesser extent in more coastal settings (Swanberg 1983). All possess photosynthetic symbionts and all endosymbionts that have been described so far are dinoflagellates related to the Scrippsiella genus (Table S1) (Swanberg 1983, Zettler et al. 1998). Among the solitary Spumellarida and Nassellarida, many species inhabiting photic layers of the oceans have endosymbiotic algae in contrast to deep dwellers which usually do not possess endosymbionts (Anderson 1983a). Caron and co-authors (1995) estimated that roughly half of the radiolarian species in surface waters of oceanic gyres possess symbiotic algae. In the Equatorial Pacific $\left(140^{\circ} \mathrm{W}\right.$ equator), up to $50 \%$ of solitary Radiolaria had algal endosymbionts (Stoecker et al. 1996).

Three kinds of algal endosymbionts, dinoflagellates, prymnesiophytes and prasinophytes, have been reported so far in solitary Radiolaria (Table S1). The most common symbionts are dinoflagellates related to the Scrippsiella genus, which are closely related to the symbiont type found in the medusa Vellela vellela (Gast \& Caron 1996) and, therefore, are distinct from the foraminiferan dinoflagellate symbionts identified as relatives to the Gymnodinium genus (Gast \& Caron 2001, Shaked $\&$ de Vargas 2006). The second most common symbionts are prymnesiophytes (Anderson et al. 1983, Anderson \& Matsuoka 1992). Their molecular taxonomy remains to be elucidated, but ultrastructural observations suggest that prymnesiophyte symbionts of Radiolaria and Acantharea are closely related (Anderson et al. 1983). Finally, green algae belonging to the prasinophytes were found in some species, such as Spongodrymus sp. and Thallassolampe margarodes (Table S1). It is noteworthy that some genera can bear different types of photobionts. For instance, Spongodrymus sp. has been observed in symbiosis with dinoflagellates, prymnesiophytes and prasinophytes (Table S1), but in contrast to benthic foraminifera only one kind of algal symbiont can be found in individual specimens. These observations raise questions about symbiont/host specificities in particular groups of Radiolaria and Foraminifera, but also certainly point out the requirement for improved taxonomic identification of both hosts and symbionts.

Algal symbionts provide their rhizarian hosts with energy from photosynthesis necessary for survival and growth in oligotrophic environments. Such symbiotic associations short-cut the traditional microbial food web and allow large protistan grazers to inhabit otherwise hostile environments (Norris 1996). Assimilation of symbiont-derived photosynthates has been demonstrated for several Radiolaria and Foraminifera species (Anderson 1983a, Lee 2006). Algal endosymbiosis, although transient, is required for normal growth and reproduction of many Rhizarian species and thus is obligate. In Foraminifera, the role of endosymbionts in growth and calcification has been clearly demonstrated (Erez 1978, Lee \& McEnery 1983, Lee 2006). In Radiolaria, there is evidence that some dinoflagellate symbionts produce sterols which may be secreted into the environment and which could render the host less vulnerable to predators or diseases (Anderson 1983b). A tight control by the hosts over the symbiont populations has been observed and influences symbiont distribution (e.g. day versus night to optimize photosynthesis) and abundances (e.g. partial digestion for energy purposes such as gametogenesis) (Anderson \& Bé 1976, Anderson 1983a).

In benthic foraminifera within the photic zone, plastid retention also appears to be obligate and may play a role in providing oxygen in low oxygen habitats as well as in providing photosynthate (Bernhard \& Bowser 1999). The role of plastids in benthic foraminifera living below the euphotic zone is a matter of speculation, although providing nitrate reductase activity has been suggested (Grzymski et al. 2002, Bernhard 2003).

\section{Ciliates}

Foissner et al. (1999) estimate that about $23 \%$ of the planktonic ciliate species (combined freshwater and marine) carry out acquired phototrophy. Acquired phototrophy occurs in at least 8 major ciliate taxa (Heterotrichea, Hypotrichia, Oligotrichida, Stichotrichia, Litostomatea, Prostomatea, Peniculia, Peritrichia) and is reported, but with less evidence, in a 9th, the Choreotrichia (see Table S2 available as supplementary material at www.int-res.com/articles/suppl/a057 p279_app.pdf). In 7 of the 8 major ciliate taxa, phototrophy is usually acquired by algal endosymbiosis, but in the Oligotrichida it is usually by plastid retention (Table S2). Interestingly, most of the ciliates with algal endosymbionts are from freshwater ponds and lakes and in most cases the algal endosymbiont is a Chlorophyte, often Chlorella sp (Table S2) (Dolan 1992, Reisser 1986). The estuarine and marine examples of algal endosymbiosis in ciliates are rare but involve a variety of algal taxa (Table S2). The coral reef ciliates Maristentor dinoferus and Euplotes uncinatus have a dinoflagellate endosymbiont (Lobban et al. 2002, 2005). Small prasinophyte endosymbionts have been observed in estuarine Oligotrichida (Jonsson 1987, Stoecker et al. 1988-1989). Populations of the marine 
photoautotrophic ciliate Myrionecta rubra (in the Litostomatea) retain organelles from cryptophytes (Johnson et al. 2007) or have a permanent cryptophyte endosymbiont (Hansen \& Fenchel 2006).

Plastid retention is very common among marine and freshwater oligotrichous ciliates, but a greater number and diversity of plastid-containing oligotrichs have been reported among the marine than freshwater species (Table S2). In marine ciliates, plastid retention occurs in some or all members of the genera Cyrtostrombidium, Laboea, Strombidium and Tontonia. L. strobila with plastids is ubiquitous in marine and estuarine waters. Among the marine oligotrichs, retention of cryptophyte, prymnesiophyte, and prasinophyte plastids has been well documented (Table S2). In early reports of 'green' oligotrichous ciliates in freshwater, it was usually assumed that the 'green' color was due to algal endosymbionts. However, it is now evident that plastid retention occurs in some very common freshwater oligotrichous ciliates including Limnostrombidium viride (formerly Strombidium viride) and Pelagostrombidium spp.; however, the source of the plastids has not been documented (Rogerson et al. 1989, Foissner et al. 1999). The freshwater ciliates Rimostrobidium velox, Halteria bifurcata and Pelagohalteria viridis have green algal endosymbionts (Foissner et al. 1999).

Ciliates with acquired phototrophy are common in aquatic ecosystems world wide, ranging in trophic status from eutrophic to oligotrophic (Tables $1 \& 2$, see also Table S2). Acquired phototrophy in ciliates can have several functions. Below we describe 4 common ecological types of ciliates with acquired phototrophy and the niches which they inhabit.

(1) Large colonial and sessile ciliates with algal endosymbionts are most common in oligotrophic, relatively high light, stable freshwater environments. Examples are photosynthetic ciliates in the Heterotrichea and Peritrichia (Table S2). These are the Kselected ciliates of the microbial food web. They are suspension feeders on small prey, such as bacteria. They have persistent algal endosymbionts although number and activity of endosymbionts may be regulated and change seasonally. Asymbiotic strains have not been observed in nature; thus, these species are considered obligate mixotrophs. Photosynthesis may cover all or part of their respiratory demands for carbon and, thus, they are probably relatively resistant to starvation. They appear to use 'excess' carbon (Hessen \& Anderson 2008) from photosynthesis in building support and protective structures such as gelatinous colonies (e.g. Ophrydium versatile), contractile stalks (e.g. Vorticella chlorellata) and some produce anti-predation compounds and/or myco-sporine-like compounds to prevent UV damage (e.g. Maristentor dinoferus and O. naumanni) (Lobban et al. 2002, Modenutti et al. 2005, Sommaruga et al. 2006).

Stentor spp. and Ophrydium spp. with algal endosymbionts can dominate the annual ciliate biomass and make an important contribution to total photosynthetic biomass in some oligotrophic lakes (Beaver \& Crisman 1989a, Bienert et al. 1991, Woelfl \& Geller 2002) (Table 1). Maristentor dinoferus is conspicuous on coral reefs in Guam (Lobban et al. 2002). However, large cell-size, sessile photosynthetic ciliates are generally rare in marine environments (Table S2), perhaps because of the lack of suitable substrates in most oligotrophic, marine planktonic ecosytems and also perhaps due to greater predation pressure on large cell-size ciliates in the marine than in the freshwater ecosystems they inhabit.

(2) Oxycline photosynthetic ciliates are common in freshwater lakes with a euphotic zone that penetrates into hypoxic or anoxic waters during stratification (Table S2). Acquired phototrophy is used by these ciliates as a source of oxygen as well as carbon.

Oxycline photosynthetic ciliates usually have green algal endosymbionts and include ciliate genera from several lineages including the Hypotrichia, Oligotrichida, Litostomatea, Prostomatea, and Peniculia (Table S2). They include large 'benthic' species, such as Euplotes daidaleos and Frontonia, that migrate into the water column from anoxic sediments during summer stratification in temperate lakes, as well as planktonic species, such as Acaryophyra and Disematostoma butschlii (Berninger et al. 1986, Beaver \& Crisman 1989b). In some cases, the algal endosymbiosis is persistent, but in many cases it is transient, with asymbiotic ciliates found in the benthos or water column during mixing (Berninger et al. 1986, Beaver \& Crisman 1989b). Thus, many of these species are facultative rather than obligate mixotrophs (Fig. 2). Although most oxycline photosynthetic ciliates have algal endosymbionts, there is an interesting example, Perispira ovum, which retains organelles from ingested Euglena. It was found at the oxic-anoxic boundary in a fjord-like estuary (Johnson et al. 1995).

Photosynthetic ciliates can reach very high population densities in thin layers within or just below the oxycline in some lakes (Berninger et al. 1986, Finlay et al. 1996, Macek et al. 2008). Finlay et al. (1996) observed ciliate populations of over $3 \times 10^{3} \mathrm{ml}^{-1}, 96 \%$ of which had algal endosymbionts, in thin layers within anoxic water of a pond (Finlay et al. 1996). They calculated that algal endosymbionts can evolve enough oxygen to meet about one-half of the respiratory demands of the ciliate hosts. Residence, for whole or part of the day, in hypoxic or anoxic waters can have many advantages for an aerobic ciliate able to obtain oxygen, including high food density and refuge from predators. 
Table 1. Location and importance of ciliates that carry out acquired phototrophy in freshwater plankton assemblages

\begin{tabular}{|c|c|c|}
\hline Location & Contribution/comments & Source \\
\hline \multicolumn{3}{|l|}{ Eurasia } \\
\hline $\begin{array}{l}\text { Lake Baikal, } \\
\text { Russia }\end{array}$ & $\begin{array}{l}\text { Contribute up to } 6 \% \text { of the under ice and } 80-90 \% \text { of the summer } \\
\text { ciliate assemblage, augment autotrophic biomass by } 30-40 \% \text {. }\end{array}$ & Obolkina (2006) \\
\hline $\begin{array}{l}\text { Small lakes, } \\
\text { southern Estonia }\end{array}$ & $\begin{array}{l}\text { Strombidium viride common in epilimnion, high densities of } \\
\text { Coleps hirtus and C. spetai in metalimnion. }\end{array}$ & Zingel \& Ott (2000) \\
\hline $\begin{array}{l}\text { Oligotrophic lakes, } \\
\text { North Europe }\end{array}$ & $\begin{array}{l}\text { Ciliate biomass in lakes above timberline dominated by large } \\
\text { photosynthetic oligotrichs. }\end{array}$ & Macek et al. (2006) \\
\hline $\begin{array}{l}\text { Alpine Lake } \\
\text { Traunsee, Austria }\end{array}$ & $\begin{array}{l}\text { Ciliates with endosymbionts up to } 25 \% \text { of total ciliate } \\
\text { abundance in surface waters. }\end{array}$ & Sonntag et al. (2006) \\
\hline $\begin{array}{l}\text { Piburger See } \\
\text { (oligo-mesotrophic lake), } \\
\text { Austria }\end{array}$ & $\begin{array}{l}\text { Mixotrophic ciliates present under ice and in } \\
\text { surface waters during summer. }\end{array}$ & $\begin{array}{l}\text { Sommaruga \& } \\
\text { Psenner (1995), } \\
\text { Macek et al. (1996) }\end{array}$ \\
\hline $\begin{array}{l}\text { Římov Reservoir } \\
\text { (eutrophic), Czech Republic }\end{array}$ & $\begin{array}{l}\text { Autotrophy covers } \sim 43 \% \text { of Pelagohalteria } \\
\text { viridis carbon requirements. }\end{array}$ & Šimek et al. (1996) \\
\hline Lake Constance, Germany & Pelagohalteria viridis abundant at onset clear-water phase. & Müller et al. (1991) \\
\hline $\begin{array}{l}\text { Gravel Pit Lake (meso- } \\
\text { eutrophic), Germany }\end{array}$ & $\begin{array}{l}\text { Coleps hirtus viridis dominant planktonic ciliate, } \\
\text { averages } 68 \% \text { of ciliate biomass. }\end{array}$ & Auer et al. (2004) \\
\hline $\begin{array}{l}\text { Priests Pot (eutrophic } \\
\text { pond), England }\end{array}$ & $\begin{array}{l}\text { Ciliates with endosymbionts abundant in oxic-anoxic boundary } \\
\text { during summer stratification; up to } 3466 \text { ciliates } \mathrm{ml}^{-1} \text { of } \\
\text { which } 96 \% \text { contain algal endosymbionts. }\end{array}$ & $\begin{array}{l}\text { Berninger et al. (1986), } \\
\text { Rogerson et al. (1989), } \\
\text { Finlay et al. (1996) }\end{array}$ \\
\hline Lake Carter (pond), England & $\begin{array}{l}\text { In July, Strombidium viride contributed } \sim 0.5 \% \text { of primary } \\
\text { production; its abundance was } 12000 \text { cells } \mathrm{l}^{-1} \text {, its chlorophyll } \\
\text { content was } 160 \mathrm{pg} \mathrm{chl} \mathrm{cell}^{-1} \text {, and its photosynthetic rate was } \\
18-54 \mathrm{pg} \mathrm{C} \text { fixed cell } \mathrm{C}^{-1} \text {. }\end{array}$ & Perriss et al. (1994) \\
\hline Lake Windermere, England & $\begin{array}{l}\text { Strombidium viride one of the dominant ciliates, especially in } \\
\text { oligotrophic section, densities of } 2.5-3.0 \text { cells } ~^{-1} \text {. }\end{array}$ & $\begin{array}{l}\text { Laybourn-Parry \& } \\
\text { Rogerson (1993) }\end{array}$ \\
\hline $\begin{array}{l}\text { Lake Pavin } \\
\text { (oligomesotrophic), France }\end{array}$ & $\begin{array}{l}\text { Mixotrophic oligotrichs abundant in euphotic zone, } 2-53 \% \\
\text { ciliate abundance and } 5-91 \% \text { of ciliate biomass; } \\
\text { S. viride dominant mixotrophic ciliate. }\end{array}$ & Carrias et al. (1998) \\
\hline Reservoir, France & Pegalohalteria viridis dominant ciliate. & Thouvenot et al. (1999) \\
\hline $\begin{array}{l}\text { Oligomesotrophic Lake, } \\
\text { France }\end{array}$ & Mixotrophic ciliates $>50 \%$ of the ciliate biomass during spring. & Amblard et al. (1993) \\
\hline Bog Lake, Germany & Mixotrophic oligotrichs dominated ciliate biomass during ice melt. & Macek et al. (2001) \\
\hline \multicolumn{3}{|l|}{ Africa } \\
\hline Lake Tanganyika, Africa & $\begin{array}{l}\text { Strombidium viride biomass is equal to or more than that } \\
\text { of phytoplankton during stable stratification, but lower } \\
\text { during mixis. Contributes most of the ciliate biomass. }\end{array}$ & $\begin{array}{l}\text { Hecky \& Kling (1981), } \\
\text { Pirlot et al. (2005) }\end{array}$ \\
\hline \multicolumn{3}{|l|}{ North America } \\
\hline $\begin{array}{l}\text { Small oligotrophic lake, } \\
\text { Pennsylvannia, USA }\end{array}$ & $\begin{array}{l}\text { Mixotrophic ciliates } 58 \% \text { of abundance and } 88 \% \text { of ciliate bio- } \\
\text { volume during summer and fall; after winter mixis, mixotrophic } \\
\text { ciliates } 5 \% \text { of abundance and } 58 \% \text { of ciliate biovolume. }\end{array}$ & Holen (2000) \\
\hline $\begin{array}{l}\text { Lake Olgethorpe, } \\
\text { Georgia, USA }\end{array}$ & $\begin{array}{l}\text { Strombidium viride found during winter mixis and summer } \\
\text { stratification; } 0.9-51.1 \% \text { ciliate abundance, } 0.1-13.4 \% \text { of ciliate } \\
\text { biomass; ciliates with endosymbionts (Paradileptus, Stokesia } \\
\text { vernalis) observed during stratification. }\end{array}$ & Pace (1982) \\
\hline $\begin{array}{l}\text { Lake McCloud (acidic, } \\
\text { oligotrophic), Florida, } \\
\text { USA }\end{array}$ & $\begin{array}{l}\text { Stentor niger }>90 \% \text { of ciliate biomass and estimated } 30 \% \text { of } \\
\text { total autotrophic biomass, Strombidium viride often } \\
\text { numerically dominant. }\end{array}$ & Bienert et al. (1991) \\
\hline $\begin{array}{l}\text { Acidic, oligotrophic lakes, } \\
\text { Florida, USA }\end{array}$ & $\begin{array}{l}\text { Stentor niger comprised annual average of } 64 \% \text { of ciliate } \\
\text { biomass, dominant in spring and summer. }\end{array}$ & $\begin{array}{l}\text { Bienert }(1987, \text { cited } \\
\text { in Beaver \& Crisman } \\
\text { 1989b) }\end{array}$ \\
\hline $\begin{array}{l}\text { Humically colored lakes, } \\
\text { USA }\end{array}$ & $\begin{array}{l}15 \% \text { of annual pelagic autotrophic biomass; most abundant } \\
\text { during summer stratification, when often contribute }>50 \% \\
\text { of autotrophic biomass. }\end{array}$ & $\begin{array}{l}\text { Beaver et al. (1988 } \\
\text { cited in Beaver \& } \\
\text { Crisman 1989b) }\end{array}$ \\
\hline $\begin{array}{l}\text { Lake Alchichica (warm, } \\
\text { monomictic), Mexico }\end{array}$ & Euplotes cf daidaleos and Pelagothrix sp. important in oxycline. & $\begin{array}{l}\text { Macek et al. (2008), } \\
\text { Peštová et al. (2008) }\end{array}$ \\
\hline \multicolumn{3}{|l|}{ South America } \\
\hline $\begin{array}{l}\text { Temperate, oligotrophic } \\
\text { lake, Chile }\end{array}$ & $\begin{array}{l}\text { Stentor araucanus, S. amethystinus, Ophrydium naumanni } \\
\text { combined: } 16 \% \text { of ciliate abundance, } 92 \% \text { of ciliate biomass, } \\
\text { and } 47 \% \text { of total zooplankton biomass. Estimated annually } \\
\text { account for } 4 \% \text { of autotrophic biomass, } 6.5 \% \text { of } \\
\text { total photosynthesis. }\end{array}$ & Woelfl \& Geller (2002) \\
\hline
\end{tabular}


Table 1 (continued)

\begin{tabular}{|c|c|c|}
\hline Location & Contribution/comments & Source \\
\hline $\begin{array}{l}\text { Ultraoligotrophic } \\
\text { lake Moreno } \\
\text { Oeste, Argentina }\end{array}$ & $\begin{array}{l}\text { During summer stratification, Ophyridium naumanni formed } \\
\text { deep chlorophyll max.; Stentor araucanus in upper epilimnion. }\end{array}$ & $\begin{array}{l}\text { Quieimalinos et al. } \\
\text { (1999), Modenutti \& } \\
\text { Balsiero (2002), } \\
\text { Modenutti et al. (2005) }\end{array}$ \\
\hline \multicolumn{3}{|l|}{ Australia } \\
\hline Australian lakes & $\begin{array}{l}\text { Large Stentor sp. } 4-69 \% \text { of total plankton photosynthesis in } \\
\text { winter, spring and autumn. }\end{array}$ & $\begin{array}{l}\text { Laybourn-Parry et al. } \\
\text { (1997) }\end{array}$ \\
\hline \multicolumn{3}{|c|}{ 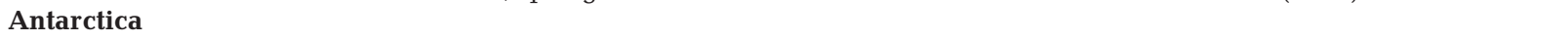 } \\
\hline Saline lakes & $\begin{array}{l}\text { Myrionecta rubra dominant ciliate and an important component } \\
\text { of phytoplankton, up to } 2.7 \times 10^{5} \text { cells } \mathrm{l}^{-1} \text {. }\end{array}$ & $\begin{array}{l}\text { Bell \& Laybourn-Parry } \\
\text { (1999), Laybourn-Parry } \\
\text { (2002) }\end{array}$ \\
\hline $\begin{array}{l}\text { Freshwater lake, } \\
\text { Vestford Hills }\end{array}$ & Strombidium viride most common ciliate sp. & $\begin{array}{l}\text { Laybourn-Parry } \\
\text { et al. (1991) }\end{array}$ \\
\hline
\end{tabular}

Table 2. Location and importance of ciliates that carry out aquired phototropy in marine plankton assemblages. MR: Myrionecta rubra; PO: plastidic oligotrichs; chl: chlorophyll; ave.: average

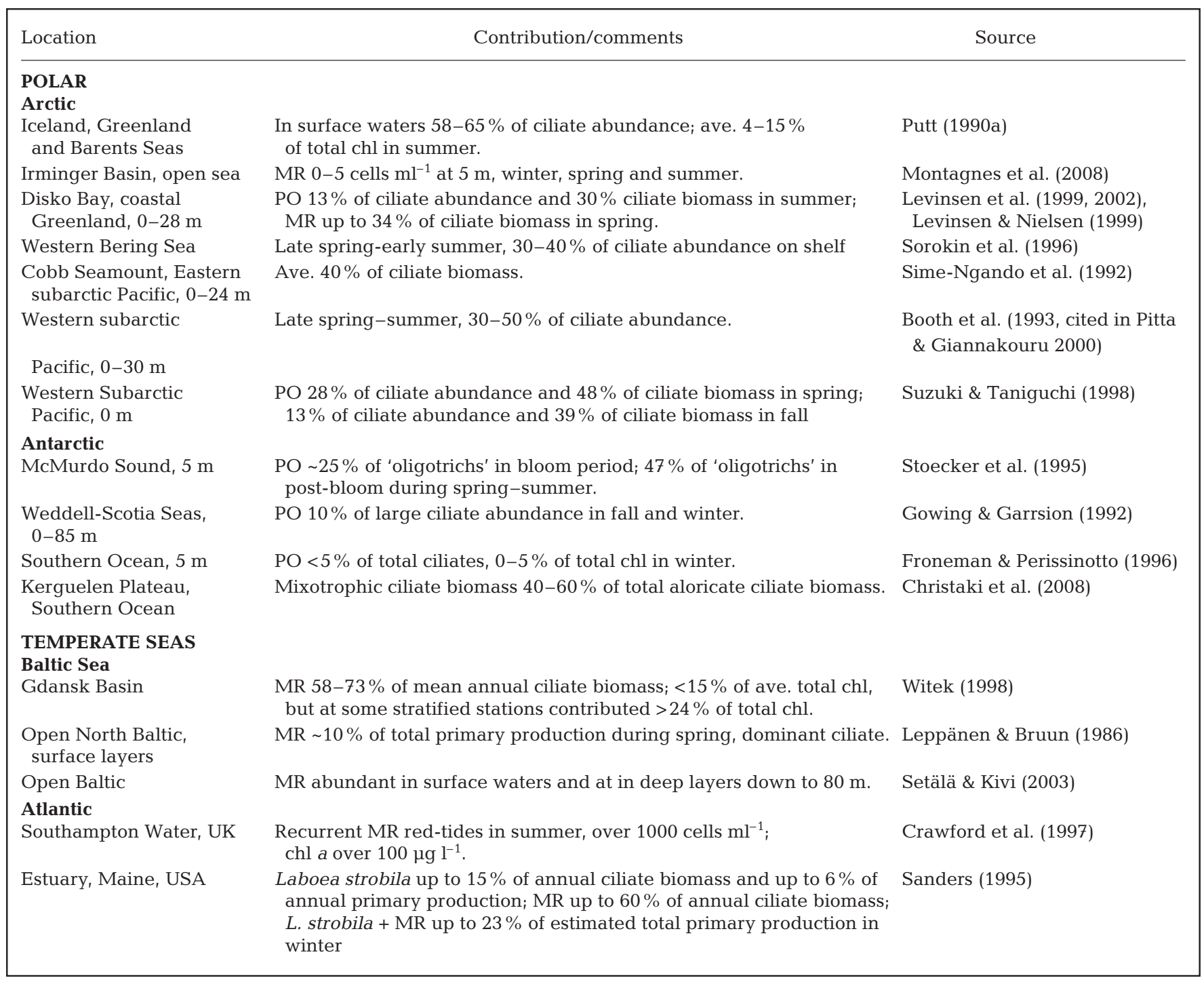


Table 2 (continued)

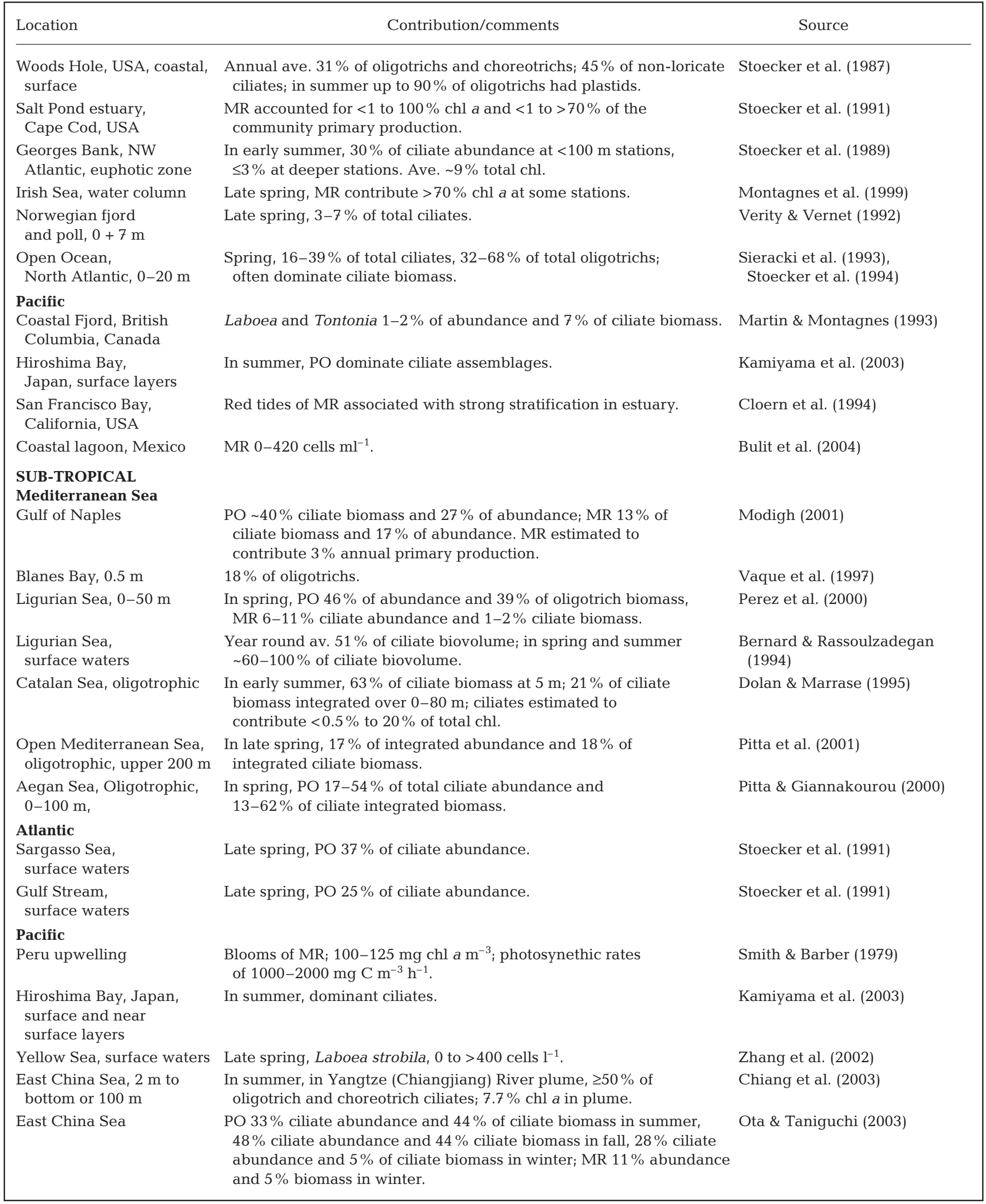


Table 2 (continued)

\begin{tabular}{|c|c|c|}
\hline $\begin{array}{l}\text { Subtropical Western } \\
\text { Pacific, } 0 \mathrm{~m}\end{array}$ & In spring, PO $45 \%$ of abundance and $35 \%$ of ciliate biomass. & Suzuki \& Taniguchi (1998) \\
\hline $\begin{array}{l}\text { Baja California } \\
\text { upwelling system }\end{array}$ & $\begin{array}{l}\text { MR red water patches with up to } 538 \text { cells } \mathrm{ml}^{-1} \text {, sometimes } \\
\text { subsurface max. }\end{array}$ & Packard et al. (1978) \\
\hline \multicolumn{3}{|l|}{ TROPICAL } \\
\hline $\begin{array}{l}\text { Equatorial Pacific, } \\
140^{\circ} \mathrm{W}, 0-120 \mathrm{~m}\end{array}$ & $\begin{array}{l}\text { El nino conditions- plastidic ciliates } 30 \% \text { of ciliate biomass; } \\
\text { relaxation of El Nino- } 7 \% \text { of ciliate biomass }\end{array}$ & Stoecker et al. (1996) \\
\hline $\begin{array}{l}\text { Continental Shelf } \\
\text { off Brazil }\end{array}$ & $\begin{array}{l}\text { Subsurface layers MR with abundances }>4000 \text { cells } \mathrm{ml}^{-1} \text {, } \\
\text { chl } a \text { up to } 79 \mathrm{\mu g} \mathrm{l}^{-1} \text {. }\end{array}$ & Owen et al. (1992) \\
\hline
\end{tabular}

(3) Planktonic, free-swimming ciliates that use photosynthesis primarily to cover some or all of their respiratory demand for carbon are common in the mixed layer, particularly under stratified conditions, in marine and freshwater ecosystems (Tables 1 \& 2). Kleptoplastidic oligotrichs are the most common and abundant photosynthetic ciliates in this niche (Table S2).

Most mixotrophic oligotrichs ingest nanophytoplankton and retain algal plastids derived from their prey (Table S2). However, some tide pool oligotrichs ingest swarmers of green macroalgae and retain their plastids and eyespots (McManus et al. 2004). Mixotrophy in plastidic oligotrichs is obligate and non-plastidic individuals are not observed (Stoecker et al. 1988, Stoecker \& Silver 1990) (Fig. 2). In the marine species, plastids from a variety of chromophytic and chlorophytic algae can be retained and many types of plastids can be observed within an individual ciliate. Little is known about plastid specificity in freshwater oligotrichs (Table S2). Plastid turn-over is rapid (usually hours) in the light, with plastids being continuously replaced through ingestion of algae (Stoecker \& Silver 1990).

Some mixotrophic oligotrichs have algal endosymbionts instead or in addition to retained plastids (Table S2). Most of the identified algal endosymbionts are prasinophytes or other green algae (Table S2). Jonsson (1987) observed 2 wk survival of Pyramimonas sp. endosymbionts in cultures of the estuarine oligotrich Strombidium reticulatum. This may indicate that endosymbionts turnover much more slowly than isolated plastids in oligotrichs. In freshwater ciliates, algal endosymbionts are observed in some planktonic Heterotrichea, Oligotrichida, Stichotrichia, Litostomatea, Prostomatea and Penicula (Table S2). Of these, Stokesia vernalis and Askenasia chlorelligera (Table S2) can be abundant in the epilimnion of lakes during summer stratification (Berninger et al. 1986, Sommaruga \& Psenner 1995).
Mixotrophic oligotrichs vary in their chlorophyll contents, photosynthetic capacities and probably in their reliance on phototrophy as a source of fixed carbon. One of the largest and most photosynthetic, Laboea strobila, is found in estuaries and oceans world-wide (Table S2) and its physiological ecology has been investigated in the laboratory and field (Table 3). Photosynthesis can contribute an estimated $6 \%$ of cell $\mathrm{C}$ $\mathrm{h}^{-1}$, while maximum ingestion is about the same (recalculated from Stoecker et al. 1988, Stoecker \& Michaels 1991). Photosynthate is used primarily to meet respiratory demand for carbon (Putt 1990b). In the light, in addition to the carbon fixation measured in ${ }^{14} \mathrm{C}$ incubations, respiratory loss of cell carbon may be spared (Stoecker \& Michaels 1991).

The effect of mixotrophy on the ability to survive starvation is light dependent. In culture, some plastid retaining oligotrichs can have high survival without food for at least $2 \mathrm{~d}$, with some individuals surviving as long as 4 to $6 \mathrm{~d}$ on a light:dark cycle (Stoecker et al. 1988-1989). Most heterotrophic ciliates quickly go into starvation mode, reducing their rates of respiration or encysting (Crawford \& Stoecker 1996). However, in the dark, plastid-retaining ciliates may be more susceptible to starvation than heterotrophic ciliates, since they do not appear to be able to reduce their dark respiration rates (Crawford \& Stoecker 1996). Their dependence on both light and prey may make them particularly vulnerable to mixing below the euphotic zone.

Among the marine and perhaps also freshwater planktonic oligotrichs, acquired photosynthesis appears to be a strategy to take advantage of algal blooms that occur at the onset of thermal stratification or that are associated with ice or ice melt (Macek et al. 1996, 2001). By storing and using photosynthetic machinery (plastids) and recycling nutrients within themselves, they may be able to functionally prolong their coupling to an algal bloom. Although mixotrophic oligotrichs may not be able to grow as fast as heterotro- 
Table 3. Myrionecta rubra and Laboea strobila. Cell size, chlorophyll a content and rates of photosynthesis, ingestion and respiration in 2 marine planktonic ciliates with acquired phototrophy - the obligate phototroph $M$. rubra and an obligate mixotroph, the plastid-retaining ciliate L. strobila. Sources are given in the footnote; rates measured on cultured (Cul.) or wild populations (W)

\begin{tabular}{|c|c|c|c|c|c|c|}
\hline \multirow[t]{2}{*}{ Species } & \multirow[t]{2}{*}{ Cell size } & \multirow[t]{2}{*}{ Chl a (pg cell $\left.{ }^{-1}\right)$} & \multirow{2}{*}{$\begin{array}{l}\text { Photosynthesis } \\
\left(\text { pg C cell }^{-1} \mathrm{~h}^{-1} \text { ) }\right.\end{array}$} & \multicolumn{3}{|c|}{ Cell specific rates $\left(\mathrm{C} \mathrm{cell}^{-1} \mathrm{~h}^{-1}\right)$} \\
\hline & & & & Photosynthesis & Ingestion & Respiration \\
\hline $\begin{array}{l}\text { Myrionecta rubra } \\
\text { (at } 15-20^{\circ} \mathrm{C} \text { ) }\end{array}$ & $\begin{array}{c}\sim 600 \mathrm{pg} \mathrm{C}_{i} \\
\sim 3300 \mu^{3}{ }^{\mathrm{a}}\end{array}$ & $8-13^{\mathrm{a}}$ & $75-85^{\mathrm{a}}$ & $\begin{array}{c}2-14 \% \\
\left(\text { at } P_{\max }\right)^{\mathrm{a}}\end{array}$ & $0.02-0.2 \%{ }^{\mathrm{b}}$ & $\sim 0.1 \%{ }^{\mathrm{a}, \mathrm{c}}$ \\
\hline $\begin{array}{l}\text { Myrionecta rubra } \\
\left(\text { at } 0-5^{\circ} \mathrm{C}\right)\end{array}$ & $3000-4200 \mu \mathrm{m}^{3}$ & $8-58^{\mathrm{e}}$ & $10-55^{\mathrm{e}}$ & $\begin{array}{l}1.8-10 \% \\
\left(\text { at } P_{\max }\right)^{\mathrm{f}}\end{array}$ & $0-0.4 \%{ }^{\mathrm{d}, \mathrm{g}}$ & \\
\hline Laboea strobila & $\begin{array}{c}\text { 9-14 ng } \mathrm{C}^{\mathrm{h}, \mathrm{i}} ; \\
\sim 110 \times 10^{3} \mathrm{~mm}^{3}\end{array}$ & $187-248^{\mathrm{h}, \mathrm{j}}$ & $\begin{array}{c}925\left(\text { at } P_{\max }\right)^{\mathrm{j}, \mathrm{k}} ; \\
260-277\left(\text { at } P_{\max }\right)^{\mathrm{k}, \mathrm{m}}\end{array}$ & $\begin{array}{l}6.4 \%\left(\text { at } P_{\max }\right)^{1} ; \\
\sim 2.8 \%\left(\text { at } P_{\max }\right)^{\mathrm{k}}\end{array}$ & $\begin{array}{c}5.9 \% \\
(\text { food saturated })^{\mathrm{j}}\end{array}$ & av. $2.1 \%{ }^{\mathrm{i}}$ \\
\hline \multicolumn{7}{|c|}{ 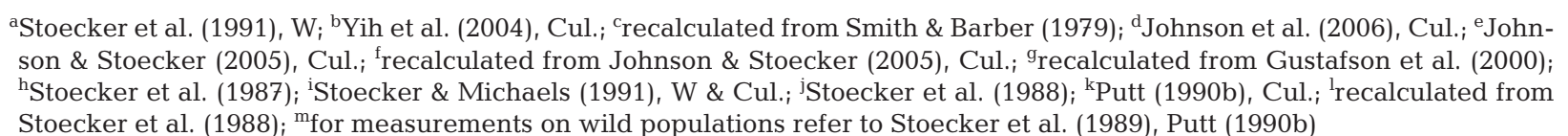 } \\
\hline
\end{tabular}

phic ciliates (Dolan \& Perez 2000), by being able to temporarily withstand food-limiting conditions without stepping-down their metabolism, they may be able to take better advantage of nanophytoplankton blooms that are temporally and spatially patchy.

Plastidic oligotrichs are relatively abundant in oligotrophic, mesotrophic and sometimes eutrophic surface waters (Tables $1 \& 2$ ). Total oligotrich abundance is positively correlated with chlorophyll in the sea and the percentage of oligotrichs that are photosynthetic is relatively constant, averaging 30\% (Dolan \& Perez 2000). At a coastal Mediterranean site, about $41 \%$ of all oligotrich species were observed to be plastidic (Laval-Peuto \& Rassoulzadegan 1988). In some oligotrophic lakes, plastidic oligotrichs dominate the ciliate assemblage during stratification (Beaver \& Crisman 1989b, Pirlot et al. 2005). In both marine and fresh waters, peak abundances coincide with stratification.

(4) Acquired phototrophy in Myrionecta rubra (Mesodinium rubrum) is cellularly and physiologically unique among ciliates. In contrast to the other photosynthetic ciliates, it is an obligate phototroph and obtains almost all its carbon from photosynthesis, and nitrogen and phosphorus from uptake of dissolved inorganic nutrients (Fig. 2). It appears to alternate between 'bloom' and 'slow growth-maintenance' life styles in the marine plankton.

Myrionecta rubra has cryptophyte plastids or endosymbionts, which give it a reddish color (Taylor et al. 1971, Smith \& Barber 1979, Hansen \& Fenchel 2006, Johnson et al. 2006, Johnson et al. 2007). It can survive and grow for long periods without feeding, but periodic ingestion of suitable cryptophytes (Teleaulax/ Geminigera clade) is necessary to maintain high photosynthetic and growth rates (Gustafson et al. 2000, Johnson \& Stoecker 2005, Park et al. 2007). Although most of its body carbon comes from photosynthesis, it requires cryptophytes as a source of plastids, nuclei and/or or- ganic growth factors (Johnson \& Stoecker 2005, Hansen \& Fenchel 2006, Johnson et al. 2007). In the absence of suitable prey it can remain photosynthetic and survive for prolonged periods (months) at low irradiance (Johnson \& Stoecker 2005, Smith \& Hansen 2007).

Myrionecta rubra is well known for its ability to form 'red water' surface or subsurface blooms and to migrate vertically (Lindholm 1985, Crawford 1989) (Table 2). M. rubra blooms in the coastal ocean are usually associated with upwelling events and estuarine blooms with nutrient delivery followed by stratification. M. rubra blooms can reach densities of over $10^{6}$ cells $\mathrm{l}^{-1}$ with chlorophyll values of over $100 \mathrm{mg}$

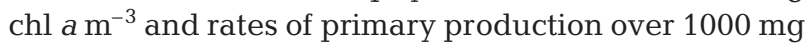
$\mathrm{C} \mathrm{m}^{-3} \mathrm{~h}^{-1}$ (Smith \& Barber 1979, Owen et al. 1992, Crawford et al. 1997). Some of the highest rates of primary production in the sea have been measured in red waters caused by this ciliate (Crawford 1989). $M$. rubra, when well supplied with suitable cryptophyte prey and nutrients, is capable of high rates of photosynthesis and spurts of rapid population growth (Johnson \& Stoecker 2005, Smith \& Hansen 2007). It may be only under these conditions that $M$. rubra inhabits well-lit, surface waters.

Myrionecta rubra occurs more routinely at low densities and can be found year-round in most estuarine and coastal waters (Crawford 1989, Montagnes \& Lynn 1989, Smith \& Hansen 2007). It is often an important member of the microplankton in winter, in turbid waters, and at or near the base of the euphotic zone, all of which are relatively low light environments (Table 2) (Lindholm \& Mork 1990, Stoecker et al. 1991, Sanders 1995, Levinsen et al. 2000, Levinson \& Nielsen 2002, Setälä \& Kivi 2003). Peak population densities can be below its compensation depth for photoautotrophy (Crawford \& Lindholm 1997). Laboratory studies show that $M$. rubra is well adapted to survive and grow slowly at low irradiances (which reduces plastid 
turnover) when cryptophyte prey is scarce (Johnson \& Stoecker 2005).

We speculate that high populations of suitable cryptophytes in the water column are a necessary antecedent to Myrionecta rubra surface blooms. Ingestion of suitable prey may result in a 'switch' in physiology, behavior and growth, resulting in surface and near surface accumulations of cells. When cryptophytes are depleted, rates of photosynthesis and growth in $M$. rubra decline and this decline is much more rapid in high than low light (Johnson \& Stoecker 2005). These physiological changes may trigger a change in photobehavior and locomotion resulting in aggregation of 'starved' $M$. rubra cells in low light environments where plastid life is extended. However, this hypothesis remains to be tested.

\section{Dinoflagellates}

Dinoflagellates are a physiologically diverse group of protists, with about half of all species carrying out strict heterotrophy and the rest capable of phototrophy. Both heterotrophic and photoautotrophic dinoflagellate species include members that are parasites, and many of the phototrophs are mixotrophic (phagocytic). Phototrophic dinoflagellates have the highest diversity of plastid types of any eukaryote lineage. In addition to their major peridinin-chlorophyll $c$ containing plastid, various dinoflagellate species may possess a permanent chlorophyll $b$ containing plastid or a chlorophyll $c$-fucoxanthin containing plastid (Delwiche 1999). Furthermore, there are at least 6 species that possess a permanent diatom endosymbiont, lacking its own cell wall, but still having an apparently unreduced second eukaryotic nucleus (Tomas \& Cox 1973, Chesnick et al. 1997). In spite of this high diversity of plastids and permanent endosymbionts, it is perhaps surprising that the dinoflagellates have relatively few examples of acquired phototrophy when compared to the ciliates or Rhizaria (see Tables S1, S2 \& S3 available as supplementary material at www.intres.com/articles/suppl/a057p279_app.pdf). While only about $1 \%$ of all dinoflagellates can be classified as carrying out acquired phototrophy, and nearly all these are rare or generally low in abundance, several species may be conspicuous due to their potential impact on human health (Table 4). The toxin producing Dinophysis spp. and the controversial harmful species Pfiesteria piscicida are both organelle-retaining dinoflagellates with global distributions in estuarine and coastal oceanic waters. Another species, Noctiluca scintillans, may possess prasinophyte endosymbionts in tropical waters and form periodic non-toxic blooms in coastal waters (Sriwoon et al. 2008).
Most dinoflagellates that carry out acquired phototrophy do so by sequestering plastids or multiple organelles from their algal prey for temporary use. Only 2 dinoflagellate species, Noctiluca scintillans and Podolampus bibes, which host endosymbionts are also capable of a free-living existence (Table S3). Thus, dinoflagellates appear to be more adapted to carrying out organelle retention than to endosymbiosis per se. Most dinoflagellates that sequester foreign organelles belong to the Gymnodiniaceae or Dinophysiaceae families. Organelle retaining members of both families were at one time misidentified as being phototrophic, due to their specific prey selection and feeding habits, which in nature results in a nearly constant presence of sequestered organelles from one type of prey. All members of the Gymnodiniaceae sequester multiple organelles from their prey and generally maintain them for 2 to 12 d (Fields \& Rhodes 1991, Skovgaard 1998). Laboratory research on Gymnodinium gracilentum and Amphidinium poecilochroum has shown that these species are capable of growing in the dark, albeit with reduced growth rates (Jakobsen et al. 2000).

Little is known about the ecology of Gymnodiniaceae that carry out acquired phototrophy. Gymnodinium acidotum has been described as excysting as colorless cells from sediment samples, before acquiring their cryptophyte organelles from free-living cells (Fields \& Rhodes 1991). While G. acidotum may be the dominant 'phytoplankter' in natural freshwater systems (Farmer \& Roberts 1990), high abundance in nature is most likely transient and linked to the availability of cryptophyte prey. Amphidinium latum and A. poecilochroum both have cryptic distributions in coastal marine environments, and appear to be associated with sediments (Larsen 1988, Horiguchi \& Pienaar 1992). A. salinum has also been suspected of carrying out kleptoplasty due to irregularities in plastid size and position (Al-Qassab et al. 2002); however, no molecular or electron microscopy data are available that support this observation. The freshwater dinoflagellate $A$. wigrense (Table S3) has also been described as possessing cryptophycean plastids (Wilcox \& Wedemayer 1985); however, it appears to be rare in lakes and ponds and its distribution is poorly known. In general, the phylogenetic positions of Amphidinium spp. that carry out acquired phototrophy are not well understood, and at least 7 additional obscure species with blue-green plastids (cryptophycean) have been reported: A. amphidinioides, A. bourrellyi, A. caerulescens, A. glaucum, A. lacunarum, A. oculatum, and A. phthartum (Calado \& Moestrup 2005).

In contrast, Dinophysis species that carry out organelle retention sequester only the plastids of their prey and have extraordinarily long retention times. While Dinophysis is a mixotroph (Jacobson \& Ander- 
Table 4. Importance of dinoflagellates that carry out acquired phototrophy in plankton assemblages

\begin{tabular}{|c|c|c|}
\hline Location & Contribution/comments & Source \\
\hline \multicolumn{3}{|l|}{ POLAR/SUB-POLAR } \\
\hline $\begin{array}{l}\text { Arctic } \\
\text { Kandalaksha Gulf, } \\
\text { White Sea }\end{array}$ & $\begin{array}{l}\text { Dinophysis acuminata and D. norvegica up to } 1550 \text { cells } 1^{-1} \\
\text { during summer. }\end{array}$ & Vershinin et al. (2006) \\
\hline Arctic Ocean & Amylax triacantha and Dinophysis norvegica widespread. & Okolodkov \& Dodge (1996) \\
\hline \multicolumn{3}{|l|}{ Antarctic } \\
\hline Ross Sea & $\begin{array}{l}\text { Unidentified dinoflagellate with Kleptoplastids (RS-Dino)maximum } \\
\text { of } 3 \times 10^{4} \text { cells } 1^{-1} \text { in sea surface and } 9 \times 10^{5} \text { cells } 1^{-1} \text { in slush; } \\
\text { estimated using qPCR. }\end{array}$ & Gast et al. (2007) \\
\hline \multicolumn{3}{|l|}{ TEMPERATE } \\
\hline \multicolumn{3}{|l|}{ Baltic Sea } \\
\hline Gulf of Gdańsk, Poland & $\begin{array}{l}0.1-4000 \text { cells l }^{-1} ; 0.5-21 \% \text { of phytoplankton biomass } \\
\text { between July-October. }\end{array}$ & Żmijewska et al. (2000) \\
\hline $\begin{array}{l}\text { Cental Baltic Sea, } \\
\text { east of Gotland }\end{array}$ & $\begin{array}{l}\text { Subsurface thermocline maximum of } 40-150 \times 10^{3} \text { cells l }^{-1} \text {; } \\
\text { surface }<5 \text { cells } l^{-1} \text {. }\end{array}$ & Carpenter et al. (1995) \\
\hline \multicolumn{3}{|l|}{ Atlantic } \\
\hline German Bight, North Sea & 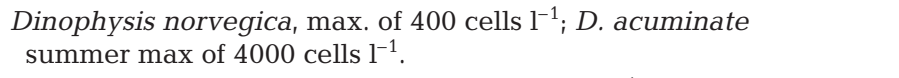 & Klöpper et al. (2003) \\
\hline $\begin{array}{l}\text { Galician Rías Bajas, } \\
\text { NW Spain }\end{array}$ & 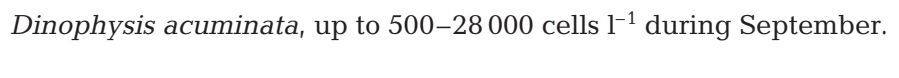 & Maneiro et al. (2000) \\
\hline $\begin{array}{l}\text { Nycklebyviken, } \\
\text { North Sea, NW Sweden }\end{array}$ & Dinophysis spp. 0-14000 cells $\mathrm{l}^{-1}$ during October-November. & Godhe et al. (2002) \\
\hline Dutch Coast, North Sea & $\begin{array}{l}\text { Noctiluca scintillans (non-symbiotic) summer abundance } \\
\text { peaks at } 35-240 \text { cells } \mathrm{dm}^{-3} \text {. }\end{array}$ & Daan (1987) \\
\hline $\begin{array}{l}\text { Estuarine and coastal } \\
\text { western North Atlantic }\end{array}$ & Pfiesteria piscicida $<2000$ cells $\mathrm{l}^{-1}$. & Lin et al. (2006) \\
\hline \multicolumn{3}{|l|}{ Pacific } \\
\hline $\begin{array}{l}\text { Okkirai Bay, } \\
\text { northern Japan }\end{array}$ & $\begin{array}{l}\text { Dinophysis fortii reached } \sim 200 \text { cells }^{-1} \text { in June; max. densities } \\
\text { were preceded by cryptomonad blooms. }\end{array}$ & Koike et al. (2007) \\
\hline \multicolumn{3}{|l|}{ SUB-TROPICAL } \\
\hline Greek coastal waters & $\begin{array}{l}\text { Dinophysis acuminata max. in February of } 85.4 \text { cells } 1^{-1} \text {; } \\
\text { blooms found above pycnocline. }\end{array}$ & Koukaras \& Nikolaidis (2004) \\
\hline $\begin{array}{l}\text { Alfacs Bay, } \\
\text { Catalonis Spain }\end{array}$ & $\begin{array}{l}\text { Dinophysis sacculus is most abundant in fall, } \\
\text { winter and spring months; to } 4000 \text { cells } 1^{-1} \text {. }\end{array}$ & Garćes et al. (1997) \\
\hline Varano Lagoon, SE Italy & $\begin{array}{l}\text { Dinophysis sacculus maximum abundance in late } \\
\text { June and November; up to } 5840 \text { cells } \mathrm{l}^{-1} \text {. }\end{array}$ & Caropo (2001) \\
\hline $\begin{array}{l}\text { Balear-Provençal, Ioian, } \\
\text { Adriatic Sea basins }\end{array}$ & Amphidinium latum present. & Gómez (2003) \\
\hline $\begin{array}{l}\text { All Mediterranean } \\
\text { sub-basins }\end{array}$ & Podolampas bipes present. & Gómez (2003) \\
\hline Gulf of Trieste & Dinophysis spp. max. in June of 2000 cells $1^{-1}$. & France \& Mozetič (2006) \\
\hline \multicolumn{3}{|l|}{ Atlantic } \\
\hline Gulf of Mexico & Dinophysis mitra present. & Balech (1967) \\
\hline \multicolumn{3}{|l|}{ TROPICAL } \\
\hline $\begin{array}{l}\text { Andamen Sea, } \\
\text { Indian Ocean }\end{array}$ & Noctiluca scintillans present at $\sim 1$ cell $^{-1}$. & Eashwar et al. (2001) \\
\hline SE India, Indian Ocean & 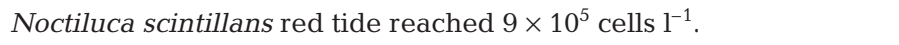 & Sahayak et al. (2005) \\
\hline $\begin{array}{l}\text { Manila Bay, Philippines, } \\
\text { Western Pacific }\end{array}$ & $\begin{array}{l}\text { Noctiluca scintillans (symbiotic) red tide (February-April) } \\
\text { reached } \sim 5000 \text { cells } 1^{-1} \text {. }\end{array}$ & Furuya et al. (2006) \\
\hline $\begin{array}{l}\text { Gulf of Thailand, } \\
\text { South China Sea }\end{array}$ & $\begin{array}{l}\text { Noctiluca scintillans (symbiotic) abundance exceeded } 100 \text { cells l}^{-1} \\
\text { from January to August at } 0.5 \mathrm{~m} \text { depth; max. of } 18.7 \times 10^{3} \mathrm{cells}^{-1} \text {. }\end{array}$ & Sriwoon et al. (2008) \\
\hline
\end{tabular}

sen 1994), some species may grow for prolonged periods as a phototroph before needing to feed (Park et al. 2008). Plastid sequestration in Dinophysis is unique, because rather than feeding directly on cryptophyte algae, it sequesters cryptophyte organelles from its ciliate prey Myrionecta rubra (Park et al. 2006). Plastid sequestration from cryptophyte algae to M. rubra, and then from $M$. rubra to Dinophysis is a fascinating 
example of the complexity of microbial food webs and their often non-hierarchical trophic dynamics. Plastids in D. fortii may persist for $40 \mathrm{~d}$ or more (Nagai et al. 2008), while plastids in D. caudata persist for over 2 mo (Park et al. 2008). While most photosynthetic Dinophysis species sequester plastids from cryptophyte algae, D. mitra has been shown to possess prymnesiophyte plastids belonging to the class Prymnesiophyceae (Koike et al. 2005). The precise identification of their haptophyte prey, however, remains elusive and the feeding and sequestration mechanism of $D$. mitra has not been described.

Plastid-retaining Dinophysis spp. are globally distributed in coastal marine environments and are known to produce diarrhetic shellfish toxins (Hallegraeff \& Lucas 1988, Lee et al. 1989). Typical 'blooms' of Dinophysis spp are $<100$ cells $\mathrm{ml}^{-1}$ (Hallegraeff \& Lucas 1988), which is a much lower abundance than most bloom-forming dinoflagellates. The reasons for high abundance of Dinophysis spp. are not well understood, but have been connected to chemical and/or physical environmental factors as well as life history dynamics (Caroppo 2001). In a 3 yr study in Okkirai Bay, Japan, high abundance of $D$. fortii was always preceded by blooms of Teleaulax spp. cryptomonads (Koike et al. 2007). The connection between these events is likely bridged by elevated abundance of Myrionecta rubra, but there was no discussion of such a link in Koike et al. (2007).

Perhaps the most basic form of organelle sequestration is carried out by the dinoflagellates Pfiesteria piscicida (Lewitus et al. 1999) and Cryptoperidiniopsis sp. (Oodiniaceae) (Eriksen et al. 2002). P. piscicida, known for its controversial association with estuarine fish kills, retains photosynthetically active plastids from cryptophyte prey (Lewitus et al. 1999). Unlike most organelle-retaining dinoflagellates, $P$. piscicida does not selectively graze one type of prey; rather they are extraordinarily opportunistic grazers that even resort to cannibalism (Burkholder \& Glasgow 1997, Feinstein et al. 2002, Vogelbein et al. 2002). The ability of $P$. piscicida to maintain sequestered plastids is low compared to other organelle retaining dinoflagellates, losing plastids in moderate light levels in 1 to $2 \mathrm{~d}$ (Feinstein et al. 2002, Lewitus et al. 2006). Less information is available on the mixotrophic capacity of Cryptoperidiniopsis spp., however, growth of the dinoflagellate is more influenced by light levels than P. piscicida (Eriksen et al. 2002).

The organisation of multiple sequesterd prey organelles appears to be a conserved trait amongst groups of dinoflagellates. Both amylax buxus and A. triacantha (Gonyaulaceae) possess foreign organelles of cryptophyte algal origin, organized in complexes resembling those found in the dinoflagellates Gymnodinium acidotum and Amphidinium latum. These complexes typically house plastids, mitochondria, and cytoplasm from their prey, and may or may not have an associated prey nucleus (Farmer \& Roberts 1990, Horiguchi \& Pienaar 1992, Koike \& Takishita 2008). The phototrophic ciliate Myrionecta rubra also maintains organelle complexes from its cryptophyte prey (Taylor et al. 1969, Hibberd 1977, Johnson et al. 2006). $M$. rubra, however, is unique in its organization of foreign organelles, as the associated prey nucleus is relatively stable and has been shown to be functional (Johnson et al. 2007). The organelle-retaining Antarctic dinoflagellate (RS-Dino) also appears to maintain a stable prey nucleus for some time (Gast et al. 2007), although the nucleus has not yet been shown to be transcriptionally active.

The dinoflagellate Podolampus bipes (Podolampaceae) has been described as possessing intact endocytobionts of dictyochophyte origin (Schweiker \& Elbrächter 2004); however, nothing is known of the nature of the potential symbiotic relationship. The heterotrophic parasite of diatoms Paulsenella cf. chaetoceratis harvests plastids from diatom cells using a feeding tube (Drebes \& Schnepf 1988) but the stability or function of these plastids are unknown.

At least 6 species of dinoflagellates possess permanent diatom endosymbionts composed of plastids, mitochondria, cytoplasm, and a nucleus (Inagaki et al. 2000, Tamura et al. 2005, Horiguchi \& Takano 2006, Pienaar et al. 2007). These dinoflagellates are phototrophic, found in freshwater or coastal regions and embayments, may either be pelagic or mostly benthic (Tamura et al. 2005), and in some cases are known to produce non-toxic red tides (Kempton et al. 2002). These dinoflagellates do not fit within the classification scheme of acquired phototrophy, rather they represent stable tertiary endosymbiotic associations, falling somewhere between acquired phototrophy and stable plastid acquisition.

\section{DOES ACQUIRED PHOTOTROPY MATTER TO AQUATIC ECOSYSTEMS?}

Not all types of acquired phototrophy are important in all aquatic ecosystems (Fig. 4). In marine ecosystems, obligate mixotrophy in plastid-retaining oligotrich ciliates and obligate phototrophy in Myrionecta rubra is important at all latitudes, whereas mixotrophy in planktonic Rhizaria is important in tropical and subtropical oceans. Mixotrophy in benthic marine protists (primarily in foraminifera) is important on tropical reefs. Acquired phototrophy in dinoflagellates is rarely of quantitative significance in marine ecosystems. However, Dinophysis spp. with acquired phototrophy are of concern in marine food webs because of their toxicity. 
In fresh water, acquired phototrophy in ciliates is important in many lakes and ponds, with plastid retention by oligotrichs particularly important in mesotrophic and oligotrophic lakes. Ciliates with green algal endosymbionts are important in the 'oxycline' in eutrophic lakes and ponds. Sessile and colonial ciliates with algal endosymbionts dominate in some oligotrophic lakes. Although dinoflagellates with acquired phototrophy occur in fresh water, there are no reports of them being quantitatively significant in food webs or in carbon flow. Freshwater foraminifera are not reported to have algal endosymbionts or plastids.

To evaluate the significance of acquired phototrophy to ecosystem processes we have chosen 3 types that are common in marine ecosystems: (1) obligate mixo-
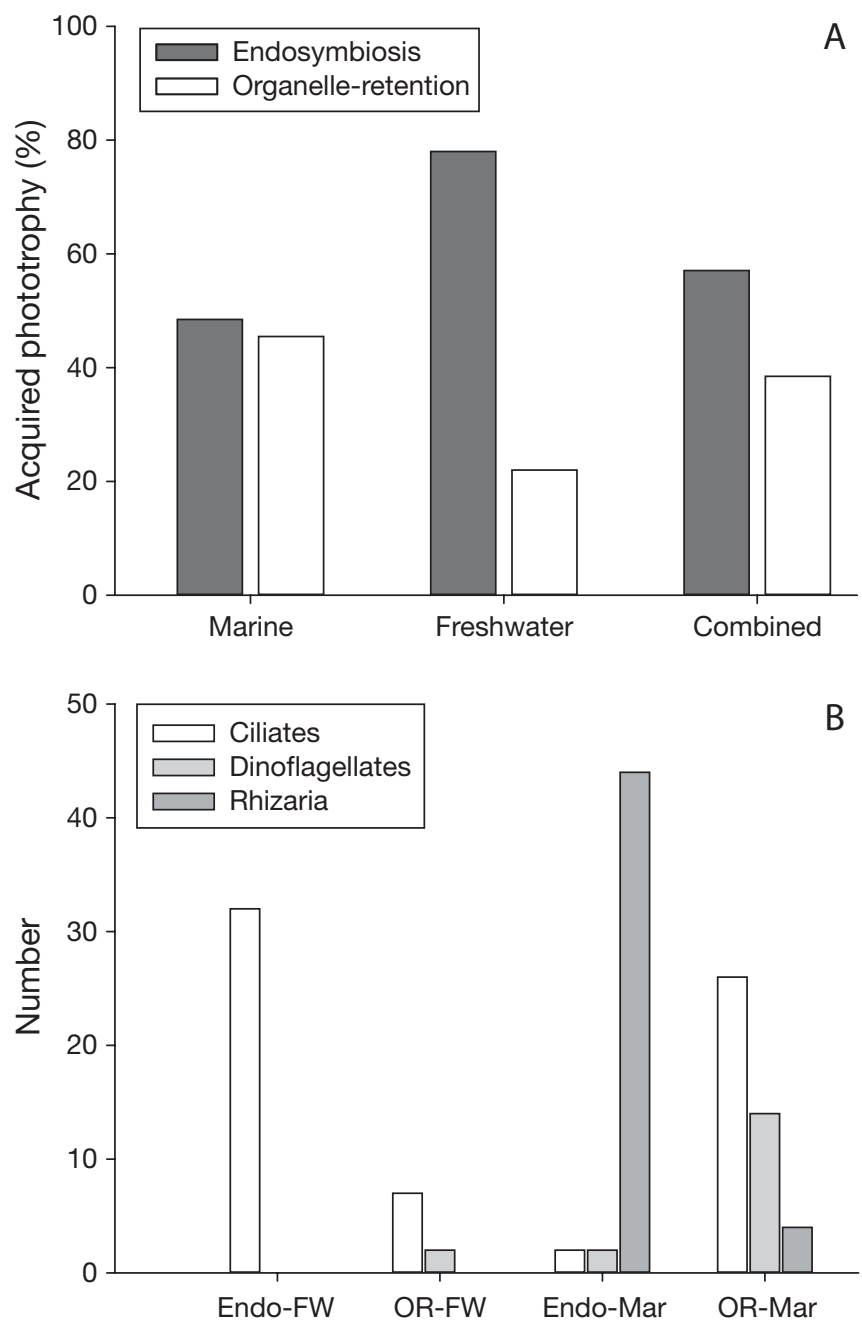

Fig. 4. (A) Percentage of the acquired phototrophic processes (endosymbiosis and organelle-retention) versus aquatic ecosystem; (B) number of species of acquired phototrophs in ciliates, dinoflagellates and rhizaria (foraminifera, radiolaria) according to ecosystem (FW: freshwater; Mar: marine) and process of acquired phototrophy (Endo: endosymbiosis; OR: organelle-retention) trophy in marine foraminifera and radiolaria; (2) obligate mixotrophy in plastid-retaining oligotrichous ciliates; and (3) photoautotrophy in the ciliate Myrionecta rubra.

\section{Foraminifera and Radiolaria}

The vast majority of symbiotic foraminifera, Polycystinea, and Acantharea inhabit oligotrophic tropical and subtropical oceans (Table 5 and also see Table S1). A major issue for accurate biomass, primary production, and ecosystem function estimates is the wide size range these organisms can exhibit (juveniles to colonies), their delicateness, and their patchy distribution. Indeed, sampling techniques introduce strong biases for such measurements, as has been demonstrated between Niskin bottles, net tows, and in situ imaging (Michaels 1988, 1991, Stoecker et al. 1996, Dennett et al. 2002).

Most planktonic foraminifera species are cosmopolitan and occupy circum-global latitudinal climatic provinces. Species such as Globigerinoides sacculifer (Brady) usually make up $20 \%$ or more of tropical planktonic foraminiferan populations (Bé \& Tolderlund 1971). Research examining the biogeography of planktonic foraminifera has observed that Orbulina universa morphospecies, one of the most common planktonic foraminifers inhabiting the surface waters of the World Ocean between $60^{\circ} \mathrm{N}$ and $50^{\circ} \mathrm{S}$, show a clear correlation between genotype distribution and chlorophyll concentration from surface waters suggesting that species distribution is controlled by variations in surface ocean productivity (de Vargas et al. 1999). Such associations could be explained by specific differences between Orbulina genotypes and feeding behavior or symbiotic association. This latter hypothesis has been proposed to explain the faunal provincialism known from the fossil record of G. rubber (Thompson et al. 1979).

Polycystinea with acquired phototrophy are found in most marine environments but are generally more restricted to the warm oligotrophic waters of the tropical and subtropical regions. Although some symbiotic Polycystinea are found in surface water of Norwegian fjords (Dolven et al. 2007), little information is available with respect to the quantitative contribution and geographical extent of symbiotic Polycystinea. Overall, total Polycystinea production and diversity decline with increasing latitude (Anderson $1983 b)$. In the Equatorial pacific $\left(140^{\circ} \mathrm{W}\right.$, equator), up to $50 \%$ of solitary Polycystinea have algal endosymbionts and contribute to over $60 \%$ of Polycystinea biomass (Stoecker et al. 1996). Maximum standing stocks of living Polycystinea bearing algal endosym- 
Table 5. Location and importance of Polycystinea (Po), Acantharea (Ac), and Foraminifera (Fo) carrying out acquired phototrophy in plankton assemblages. PP: primary production; TPP: total primary production; ave.: average

\begin{tabular}{|c|c|c|}
\hline Location & Contribution/comments & Source \\
\hline \multicolumn{3}{|l|}{ SUB-TROPICAL } \\
\hline Sargasso Sea, Bermuda & $\begin{array}{l}\text { Ac and Fo accounted respectively for } 0.41 \text { and } 0.06 \% \text { of TPP in surface } \\
\text { water over a } 2 \text { yr ave.; sarcodines ave. } 21 \% \text { of PP for the }>70 \mu \mathrm{m} \\
\text { cell size fraction. }\end{array}$ & Caron et al. (1995) \\
\hline $\begin{array}{l}\text { Central North Pacific, } \\
\text { VERTEX station }\end{array}$ & $\begin{array}{l}\text { Over } 18 \mathrm{mo} \text {, Ac abundances reached up to } 4 \text { cells l}^{-1} \text { and their PP was } \\
<4 \% \text { of the TPP; they accounted for } 6-35 \% \text { of PP by plankton }>100 \mu \mathrm{m} \text {. }\end{array}$ & Michaels (1991) \\
\hline $\begin{array}{l}\text { Central North Pacific } \\
\text { and Atlantic }\end{array}$ & $\begin{array}{l}\text { Data integrated over } 150 \mathrm{~m} \text { depth demonstrated that colonial Radiolaria } \\
\text { contributed up to } 10 \% \text { of the living microbial biomass }(>2 \mu \mathrm{m}) \text { and } 6-12 \% \\
\text { of the total living biomass in the Atlantic and Pacific; they contributed } \\
\text { up to } 9 \% \text { of the TPP in the eastern North Pacific gyre. }\end{array}$ & Dennett et al. (2002) \\
\hline $\begin{array}{l}\text { Central North Pacific, } \\
\text { CLIMAX station }\end{array}$ & $\begin{array}{l}\text { Ac abundances reached } 10-40 \text { cells } \mathrm{l}^{-1} \text {; their integrated abundances } \\
\text { up to } 2 \times 10^{6} \mathrm{~m}^{-2} \text {. }\end{array}$ & Beers et al. (1975) \\
\hline $\begin{array}{l}\text { Sargasso Sea, } \\
\text { Bermuda Atlantic Time } \\
\text { Series (BATS) }\end{array}$ & $\begin{array}{l}\text { Integrated over the upper } 150 \mathrm{~m} \text {, Fo abundance was } \sim 10^{5} \mathrm{~m}^{-2} \text { and their } \\
\text { ave. biomass } 1.4 \mathrm{mg} \mathrm{C} \mathrm{m}^{-2} \text {; Ac abundance was } \sim 10^{6} \mathrm{~m}^{-2} \text { and their bio- } \\
\text { mass } 2.8 \mathrm{mg} \mathrm{C} \mathrm{m}{ }^{-2} \text {; Po were mostly colonial and too sparse for accurate } \\
\text { abundance estimates, their ave. integrated biomass was } 2.6 \mathrm{mg} \mathrm{C} \mathrm{m}^{-2} \text {. }\end{array}$ & Michaels et al. (1995) \\
\hline Gulf of Aden & $\begin{array}{l}\text { Colonial Po of the Collozoum genus reached abundances of } \\
16000 \text { to } 20000 \text { colonies } \mathrm{m}^{-3} \text {. }\end{array}$ & Khmeleva (1967) \\
\hline Gulf of Eilat, Red Sea & $\begin{array}{l}\text { Benthic Fo genera Amphisorus and Amphistegina were found at } \\
\text { abundances of } 10^{5} \text { to } 10^{6} \text { cells } \mathrm{m}^{-2} \text { in patches. }\end{array}$ & Lee \& McEnery (1983) \\
\hline \multicolumn{3}{|l|}{ TROPICAL } \\
\hline South China Sea & $\begin{array}{l}\text { Several solitary Po genera presented ave. abundances of } 2234 \text { ind. } \mathrm{m}^{-3} \\
\text { at } 0 \text { to } 75 \mathrm{~m} \text { depth, } 939 \text { ind. } \mathrm{m}^{-3} \text { at } 75 \text { to } 150 \mathrm{~m} \text { depth and } 157 \text { ind. } \mathrm{m}^{-3} \\
\text { at } 150 \text { to } 250 \mathrm{~m} \text { depth. }\end{array}$ & Zhang et al. (2002) \\
\hline $\begin{array}{l}\text { Equatorial Pacific, } 140^{\circ} \mathrm{W} \\
\text { integrated data } 0 \text { to } 120 \mathrm{~m}\end{array}$ & $\begin{array}{l}\text { During El Niño conditions plastidic Ac, Radiolaria, and Fo contributed } \\
\text { to } \sim 45,60 \text {, and } 85 \% \text { of Ac, Radiolaria, and Fo biomass, respectively; } \\
\text { during the relaxation of El Niño plastidic Aca, Radiolaria and Fo } \\
\text { contributed to } \sim 85,70 \text {, and } 75 \% \text { of Ac, Radiolaria, and Fo biomass, } \\
\text { respectively. }\end{array}$ & Stoecker et al. (1996) \\
\hline $\begin{array}{l}\text { Equatorial Pacific, } \\
\text { Galapagos }\end{array}$ & $\begin{array}{l}\text { Fo, Radiolaria and Ac abundances reached up to } 3.3,6 \text {, and } 30 \text { cells l}^{-1} \text {, } \\
\text { respectively; integrated abundance of Ac over the upper } 150 \mathrm{~m} \text { was on } \\
\text { av. } 3.41 \times 10^{5} \text { cells } \mathrm{m}^{-2} \text { with the highest concentration in the upper } 20 \mathrm{~m} \text {; } \\
\text { at most they accounted for } 4 \% \text { of total chl } a \text { and up to } 41 \% \text { of the PP. }\end{array}$ & Michaels (1988) \\
\hline $\begin{array}{l}\text { Western Sargasso sea, } \\
\text { cape Florida }\end{array}$ & $\begin{array}{l}\text { Radiolaria, Ac, and Fo integrated abundances over the upper } 50 \mathrm{~m} \\
\text { were } 0.24 \text { to } 0.34 \times 10^{5}, 1.71 \times 10^{5} \text {, and } 0.08 \text { to } 0.32 \times 10^{5} \text { cells m}^{-2} \text {, } \\
\text { respectively. }\end{array}$ & Michaels (1988) \\
\hline $\begin{array}{l}\text { Hawaii and central } \\
\text { pacific atoll }\end{array}$ & $\begin{array}{l}\text { Benthic foraminifera genus Amphistegina represented } \\
25 \text { to } 90 \% \text { of sand-sized sediments. }\end{array}$ & $\begin{array}{l}\text { Hallock Muller (1976), } \\
\text { McKee et al. (1959) }\end{array}$ \\
\hline
\end{tabular}

bionts are usually found at around 75 to $100 \mathrm{~m}$ (central sub-arctic Pacific) (Tanaka \& Takahashi 2008). In contrast, colonial radiolarians can be abundant in the subsurface on calm days (Anderson 1983b, Dennett et al. 2002), with extreme abundances of Collozoum sp. reaching up to 20000 colonies $\mathrm{m}^{-3}$ reported in the Gulf of Aden (Khmeleva 1967). Notably, several species have been observed in Antarctic and Arctic waters, as well as boreal zones of the Atlantic, but in less abundance than in tropical waters (Anderson 1983b).

In contrast to solitary Polycystinea, Acantharea clearly predominate in subsurface water where they are frequently more abundant than Polycystinea and Foraminifera (Beers \& Stewart 1970). Acantharea could occasionally account for up to $20 \%$ or more of the carbon fixation in the upper euphotic zone of the oligotrophic ocean (Michaels 1988). In the Equatorial Pacific, Acantharea reached abundances of up to 30 cells $\mathrm{l}^{-1}$ at the surface but declined sharply below $20 \mathrm{~m} \mathrm{(90 \%}$ of cells were at the surface). Acantharea densities ranged from 4 to 7 cells $\mathrm{l}^{-1}$ in the Equatorial Atlantic and North Pacific central gyre (Bishop et al. 1977, Bishop et al. 1978, Michaels 1991), and up to $30{\text { cells } 1^{-1}}^{-1}$ in the Southeast Atlantic (Graham et al. 1976, Bishop et al. 1978). In the North pacific central gyre, the biomass 
of Acantharea reached 6.8 to $56.7 \mathrm{mg} \mathrm{C} \mathrm{m}^{-2}$ and did not show a seasonal pattern (Michaels 1991). In the upper $20 \mathrm{~m}$, symbiont carbon fixation in Acantharea was < $\%$ of the total primary production and 6 to $35 \%$ of primary production by plankton $>100 \mu \mathrm{m}$.

\section{Plastid-retaining oligotrichs}

Plastid-retaining ciliates are grazers and consume small phytoplankton, and as such are a component of the microzooplankton. In polar and temperate seas, they can contribute up to 40 to $60 \%$ of ciliate abundance and biomass in late spring and summer (Table 2). They are also important in subtropical seas (Table 2); for example, in the Gulf of Naples on an annual basis they contribute $\sim 27 \%$ of ciliate abundance and $40 \%$ of ciliate biomass (Modigh 2001) and in surface waters of the Ligurian Sea they contribute $\sim 51 \%$ of ciliate biovolume (Bernard \& Rassoulzadegan 1994). In the East China Sea, plastidic oligotrichs account for 33 to $48 \%$ of ciliate abundance and $44 \%$ of ciliate biomass in summer and fall (Ota \& Taniguchi 2003). Less information is available on their abundance in tropical seas. In the equatorial Pacific, plastidic ciliates contribute $\sim 30 \%$ of ciliate biomass during El Nino conditions and $\sim 7 \%$ during relaxation of El Nino conditions (Stoecker et al. 1996).

Plastidic oligotrichs usually contribute $<10 \%$ of total chlorophyll in the marine plankton (Stoecker et al. 1989, Putt 1990a, Dolan \& Marrase 1995, Sanders 1995, Froneman \& Perissinotto 1996, Perez et al. 2000, Chiang et al. 2003). The average annual contribution is probably <1\%. Assuming plastidic ciliates have chlorophyll-specific photosynthetic rates similar to phytoplankton (Stoecker et al. 1988) (Table 3), in most marine planktonic ecosystems they are estimated to make a small contribution to total annual primary production (Table 2). During stratification, when the phytoplankton biomass is low and dominated by picoand nanophytoplankton, photosynthesis by ciliates can be important in the $>20 \mu \mathrm{m}$ size class (Stoecker et al. 1989, Putt 1990a).

Planktonic ciliates are an important source of food for copepods in marine ecosystems (reviewed in Calbet \& Saiz 2005). Although phytoplankton biomass is at least $10 \times$ higher than planktonic ciliate biomass, ciliates comprise on average $30 \%$ of copepod daily rations in marine ecosystems (Calbet \& Saiz 2005). In the upper layers of the sea, oligotrichs usually dominate the planktonic ciliate assemblage and about $30 \%$ of the oligotrichs retain plastids (Dolan \& Perez 2000). Plastid retention, by influencing the gross growth efficiency of ciliates, could have a significant impact on ciliate production and transfer of phytoplankton- derived carbon from the microbial food web to copepods and the 'classical' food chain.

Plastidic oligotrichs may have higher trophic efficiencies for ingested carbon than heterotrophic ciliates because respiratory and excretory needs for carbon are supplemented by photosynthesis (Putt 1990b). Assimilation efficiencies of 80 to close to $100 \%$ and gross growth efficiency (GGE) of $\sim 30 \%$ are commonly assumed for heterotrophic ciliates (Straile 1997, Landry \& Calbet 2004). Based on these efficiencies, we can assume that $\sim 70 \%$ of ingested $\mathrm{C}$ is respired in heterotrophic ciliates. In some plastid retaining oligotrichs, up to $100 \%$ of the respiratory demand for carbon can be met by photosynthesis in the light (Stoecker \& Michaels 1991) (Table 3). Stored photosynthate (mostly polysaccharide) is preferentially respired by the ciliates in the dark (Putt 1990b). If we assume that plastidic ciliates can cover respiratory demand for carbon for $12 \mathrm{~h} \mathrm{~d}^{-1}$ (sparing $\sim 35 \%$ of ingested carbon from respiration), it is possible that under ideal conditions the GGE of plastidic ciliates for ingested carbon could be as high as $65 \%$. Plastidic oligotrichs comprise $\sim 30 \%$ of the marine planktonic ciliates, so plastid retention may increase average trophic efficiency of the total ciliate assemblage for ingested carbon from 30 to $40 \%$.

An increase in GGE from 30 to $40 \%$ potentially has a substantial effect on microzooplankton production and on transfer of carbon to mesozooplankton (Landry \& Calbet 2004). Under average conditions, ciliates are estimated to provide about $30 \%$ of the diet of copepods (Calbet \& Saiz 2005); under these conditions we calculate that plastid-retention would only boost trophic transfer of fixed carbon to copepods by $\sim 1 \%$. In low chlorophyll waters approximately $50 \%$ of the diet of copepods is ciliates (Calbet \& Saiz 2005); we calculate that acquired phototrophy in marine oligotrichs could boost trophic transfer of carbon from primary production to copepods under these conditions by $\sim 7 \%$. This potential boost has not been considered in most pelagic food web and biogeochemical models.

An increase in the average GGE of planktonic ciliates should also influence nutrient regeneration. If GGE of the ciliate trophic link is increased by $10 \%$, then it is likely that regeneration of inorganic nutrients and net respiration of carbon by the ciliates in the euphotic zone should be decreased by $10 \%$. During stratification, regeneration of nitrogen by grazers is important for growth of small phytoplankton. Thus, mixotrophy in ciliates may slightly decrease gross 'algal' primary production. However, this is unlikely to have a negative effect on metazoan tropho-dynamics, because of the number of trophic transfers (and hence losses of carbon due to respiration and excretion) between small phytoplankton and metazoan grazers. 


\section{Myrionecta rubra}

Myrionecta rubra is likely one of the most widespread and abundant ciliates in marine ecosystems, with a nearly constant presence in coastal plankton assemblages (Lindholm 1985, Crawford 1989) (Tables 2 \& S2). It has a global distribution, and is commonly found within estuaries, fjords, continental shelf environments, and upwelling zones (Taylor et al. 1971, Lindholm 1985). For many years M. rubra was misidentified in plankton studies, and in fact is still frequently grouped as heterotrophic microzooplankton in trophic studies (Crawford 1989, McManus et al. 2007, van Beusekom et al. 2007). M. rubra is mostly phototrophic in its physiology, but feeds on cryptophyte algae to acquire organelles or growth factors (Gustafson et al. 2000, Hansen \& Fenchel 2006, Johnson et al. 2007). Ingestion of cryptophyte algae represents a negligible $(<5 \%)$ contribution to its carbon growth requirements (Yih et al. 2004) and cellular chlorophyll content (Johnson \& Stoecker 2005). The phototrophic capabilities of $M$. rubra are well described in both field (Smith \& Barber 1979, Stoecker et al. 1991) and laboratory settings (Johnson \& Stoecker 2005, Johnson et al. 2006).

One of the most striking features of Myrionecta rubra is its extremely high motility (Lindholm 1985). $M$. rubra cells can obtain a velocity of up to $1.2 \mathrm{~cm} \mathrm{~s}^{-1}$ during its 'jumps', propelled by cilia on the posterior end of the cell (Fenchel \& Hansen 2006). This capacity for motility allows the ciliate to move extraordinary distances during a diel vertical migration, and explains why the ciliate is routinely found in discrete layers (Lindholm \& Mork 1990, Olli 1999). In stratified fjords, M. rubra has been shown to accumulate near anoxic boundaries (Lindholm 1985, Lindholm \& Mork 1990). Such vertical migrations are likely critical for the ciliate to acquire inorganic nutrients near the base of the mixed surface layer.

In upwelling zones off Peru, discrete populations of Myrionecta rubra can move between $30 \mathrm{~m}$ and the surface between early morning and midday (Sorokin \& Kogelshatz 1979). Dugdale et al. (1987) surmised that vertical migrations of motile bloom forming phytoplankton such as $M$. rubra might play a key role in the transport of heat in the eastern boundary Peruvian system, absorbing upward of $99 \%$ of incoming radiation. During $M$. rubra blooms the ciliate is often observed forming discrete subsurface patches or lenses (Lindholm 1985). The formation of subsurface layers may be a phototaxic response to optimal light levels, while avoiding the surface may be a negative phototaxic response to saturating light intensities. In a red water event off Brazil, $M$. rubra formed a subsurface layer exceeding 4000 cells $\mathrm{ml}^{-1} 1$ to $2 \mathrm{~m}$ below the surface, and was associated with slight changes in temperature directly above the ciliate (Owen et al. 1992). The subsurface lens was thought to be the cause of temperature variation in the mixed surface layer, absorbing nearly all incoming surface radiation and shading the photic zone below the layer of cells (Owen et al. 1992). Thus, blooms of $M$. rubra are dynamic events, influencing heat and nutrient distribution, and creating microscale patches of food for grazers in upper mixed layers.

Myrionecta rubra is an abundant and important phototroph in numerous near shore aquatic ecosystems (Table 2). In the open northern Baltic sea M. rubra is the dominant ciliate species during spring, representing $10 \%$ of total phytoplankton production and $2 \%$ of the total biomass (Leppänen \& Bruun 1986). Similar values of 6 to $9 \%$ of phytoplankton biomass and production have also been shown for M. rubra in the Gdańsk Basin of the southern Baltic Sea (Witek 1998). In the Georges Banks and Gulf of Maine, M. rubra, along with the oligotrich ciliate Laboea strobila, contributes 1 to $7 \%$ of total phytoplankton fixed carbon, and 14 to $90 \%$ of microplankton fixed carbon (Stoecker et al. 1989). In shallower stations, $M$. rubra represents $30 \%$ of total ciliate biomass while at deeper stations it is rare $(3 \%)$ (Stoecker et al. 1989). Similar low levels of $M$. rubra have been reported in offshore environments of the North Atlantic (Montagnes et al. 2008) and western Pacific Ocean (Gómez 2007). In a tropical upwelling region of the South Brazil bight, M. rubra was consistently present during a winter cruise, representing one third of total ciliate abundance, and $>20 \%$ of the total microzooplankton biomass (McManus et al. 2007).

Myrionecta rubra has a high photosynthetic rate that is comparable to or higher than other phytoplankton groups. $M$. rubra cells isolated from a temperate salt pond in Massachusetts, USA, had chlorophyll-specific rates of around $10 \mathrm{pg} \mathrm{C}(\mathrm{pg} \mathrm{chl} a)^{-1} \mathrm{~h}^{-1}$, while samples of a red water bloom of the ciliate off Peru reached 16.8 pg $\mathrm{C}(\mathrm{pg} \mathrm{chl} \mathrm{a})^{-1} \mathrm{~h}^{-1}$ (units recalculated from Smith \& Barber 1979). While the mixotrophic oligotrich ciliate Laboea strobila has a much higher cellular photosynthetic rate (Table 3) than M. rubra due to its large size, its chlorophyll-specific rate is lower, at $3.7 \mathrm{pg} \mathrm{C}(\mathrm{pg} \mathrm{chl} \mathrm{a})^{-1} \mathrm{~h}^{-1}$ (Stoecker et al. 1988). An Antarctic culture of M. rubra has been shown to have a much lower chlorophyllspecific rate of 0.6 to $1.25 \mathrm{pg} \mathrm{C}(\mathrm{pg} \mathrm{chl} \mathrm{a})^{-1} \mathrm{~h}^{-1}$ (Johnson \& Stoecker 2005, Johnson et al. 2006); however, lower values are typical for $\mathrm{P}_{\max }{ }^{\text {chl }}$ in polar phytoplankton (Cota et al. 1994). Respiration rates for $M$. rubra are relatively low (Table 3) compared to other ciliates (Crawford 1989, Stoecker \& Michaels 1991, Stoecker et al. 1991); however, Fenchel \& Hansen (2006) estimated that at high jumping frequencies, M. rubra may use $30 \%$ of its energy for motility and only $3 \%$ when resting. Maximum growth rate of temperate $M$. rubra strains has been 
measured at around $0.5 \mathrm{~d}^{-1}$ (Smith \& Barber 1979, Yih et al. 2004); for a polar strain this is around $0.2 \mathrm{~d}^{-1}$ (Johnson \& Stoecker 2005).

Although Myrionecta rubra has been described as lacking an oral cavity (Lindholm et al. 1988) and thought to be incapable of feeding (Crawford 1989), studies on cultures of the ciliate have revealed a capacity for ingesting cryptophyte algae (Gustafson et al. 2000). M. rubra is also known to feed on bacteria (Myung et al. 2006), but neither cryptophyte algae nor bacteria appear to be an important source of carbon for growth in non-limiting light irradiances. Hansen \& Fenchel (2006) found that 1 prey cell ingested per generation of $M$. rubra is sufficient for maintaining maximum growth rates in culture. While temperate strains of $M$. rubra can ingest up to 9 cryptophyte cells per day, such ingestion rates do not further enhance growth rates (Yih et al. 2004, Hansen \& Fenchel 2006). Both temperate and polar strains of M. rubra can survive for $50 \mathrm{~d}$ without feeding, although the temperate strain experiences greater mortality (Smith \& Barber 1979, Johnson \& Stoecker 2005). M. rubra's capacity for ingesting bacteria increases in low light (to 150 bacteria grazer ${ }^{-1} \mathrm{~h}^{-1}$ ), potentially acting as an important source of organic material in light-limited conditions (Myung et al. 2006). Supplementation of growth with ingested bacteria may be important in deep low-light populations of $M$. rubra and in over-wintering polar populations.

Grazing on Myrionecta rubra has received relatively little attention, and it is thought that the high motility of $M$. rubra assists in its escape from potential grazers (Fenchel \& Hansen 2006). However, M. rubra is the main prey of photosynthetic members of the dinoflagellate Dinophysis (Nagai et al. 2008), which probably capture M. rubra through ambush, considering their much lower motility. The copepod Oithona spp. ingests ciliates (including M. rubra) and flagellates preferentially over other nano-microplankton in the spring, while during summer and winter, clearance rates are highest for Strombidium spp. and M. rubra (Castellani et al. 2005). In a Baltic Sea inlet, Lindholm \& Mörk (1990) observed apparent grazing on M. rubra by rotifers and the ciliate Didinium sp. During red water events of M. rubra, digestive glands of bivalves are frequently observed to turn pinkish due to filter feeding on the ciliate (Carver et al. 1996). In certain regions, persistent red water blooms of $M$. rubra have been associated with fish and invertebrate mortality due to declines in dissolved oxygen (Horstman 1981).

\section{IMPORTANCE IN BIOGEOCHEMICAL CYCLES}

Planktonic Rhizaria are large protists some of which possess exoskeletons made of calcium carbonate
(Foraminifera), silicate (Polycystinea), or strontium sulfate (Acantharea). Acquired phototrophy (mixotrophy) allows these large protists to thrive in oligotrophic areas, which are otherwise dominated by very small eukaryotes. Therefore, these mixotrophs are important contributors to sinking material, enhancing particle flux to the deep ocean. The size of an organism is a major factor determining its sinking rate and hence its influence on carbon flux and, depending on the composition of its exoskeleton, on the cycles of particular elements. Food webs, sedimentation and biogeochemical cycles would be very different in the world's ocean without these large Rhizaria that are dependent on acquired phototrophy.

Foraminifera and Polycystinea present an excellent fossil record and are widely used by geologists and paleo-oceanographers in reconstruction of past climates and oceanic conditions (Steineck \& Casey 1990). The impact of Rhizaria on oceanic biogeochemical cycles is significant; however, although their fluxes have been studied by geologists, the underlying biology and ecology of Rhizaria responsible for these fluxes is not well known.

\section{Carbon}

Rhizaria inhabiting vast areas of the oceans represent a substantial biomass of organic matter and their implication in the global carbon cycle is significant. The sinking of a few, very large cells can constitute a large fraction of the carbon flux (Goldman 1988). Although, Acantharea, Polycystinea and Foraminifera contribute significantly to carbon flux. On average (over 3 cruises), they accounted for $15.5 \%$ of total carbon flux during short-term trap deployment at the BATS sampling station near Bermuda, and up to $43 \%$ when large Radiolaria and Foraminifera were present (Michaels 1988). Over an 18 mo period in the central north Pacific gyre, exports of Acantharea by sinking of intact cells from the euphotic zone were at least 2 to $6 \%$ of standing stock per day and represented up to $9 \%$ of the total sinking organic carbon flux (Michaels 1991).

Acantharea can contribute significantly to the primary productivity of oligotrophic seas. Rates of carbon export are comparable to the rate of carbon fixation by the symbionts in the Acantharea population (Michaels 1991). Combined production rate and seasonal abundances of Acantharea and Foraminifera reached $5 \%$ of total annual primary production in Sargasso Sea waters. Symbiont carbon production was equivalent to $9,39,84$, and $19 \%$ of the total organic carbon weights of Acantharea, Foraminifera, solitary Radiolaria, and colonial Radiolaria, respectively (Caron et al. 1995). 
Spero \& Parker (1985) estimated that the contribution from foraminifera symbionts to total primary production would amount to $\sim 1 \%$, reaching $25 \%$ in patches (Spero \& Parker 1985). In the Gulf of Aden, colonial Radiolaria were estimated to fix 3 times as much carbon as the phytoplankton (Khmeleva 1967, Taylor 1990).

In addition to the organic carbon export, Foraminifera have a calcium carbonate exoskeleton which makes them particularly relevant to the carbon cycle. The symbiont-bearing Foraminifera are estimated to presently produce at least 130 million tons of calcium carbonate per year and to contribute $\sim 5 \%$ of the annual carbonate production in reef and shelf areas and $\sim 2.5 \%$ of the total calcium carbonate in the global ocean (Langer 2008). Investigations of sinking speeds for various foraminifera species demonstrated that most planktonic foraminifera with a cell size $>150 \mu \mathrm{m}$ reach $3800 \mathrm{~m}$ depth in 3 to $12 \mathrm{~d}$ depending upon shell weight and presence or absence of spines (Takahashi \& Bé 1984). Foraminifera depend on their symbionts for growth and carbonate production. Photosynthesis and calcification are directly proportional to light intensity and 2 to 3 times higher than in the dark (Duguay \& Taylor 1978, ter Kuile \& Erez 1987).

Benthic foraminifera are abundant in the euphotic shallow benthic zones of tropical and semi-tropical seas, they are ubiquitous members of coral-reef associated ecosystems worldwide and play important roles in biogeochemical mineral cycling (Sournia 1976, Lee \& McEnery 1983, Langer 2008). Larger foraminifera are so abundant that they were called 'living sands' (Lee 1998). The Amphistegina genus is one of the most abundant and widespread larger foraminifera and produces nearly a quater of beach sands in Hawaii (Hallock Muller 1976) and $>90 \%$ of the sand-sized sediments in a central Pacific atoll (McKee et al. 1959).

\section{Silica}

The silica cycle is strongly dominated by diatoms in eutrophic and coastal ecosystems. However, in the vast majority of the ocean surface Polycystinea, together with Phaeodarea (non-symbiotic rhizarian taxa), have a major impact on the silica cycle (Silver \& Gowing 1991). To our knowledge, no studies have focused specifically on the impact of species carrying algal endosymbionts on the silica cycle.

Noteworthy, the silica cycle is tightly coupled to the Barite cycle, the latter being formed by decaying silica. Thus, there is a strong correlation between the dissolved Barite and Silica cycle in the ocean. Particulate Barite is used as a proxy for organic carbon remineralization and is extensively used in paleo-oceanography (Bishop 1988, Dehairs et al. 2008).

\section{Strontium}

The strontium cycle in the ocean is not well known. However, because the strontium-90 isotope is a long life waste product of uranium fission, some studies carried out after World War II focused on strontium accumulation in marine organisms (Bowen 1956). As previously mentioned, Acantharea are abundant in oceanic subsurface water and hence play an important role in the ocean's Strontium budget (Bernstein et al. 1987). However, very little is known with respect to their quantitative impact on the Strontium cycle. Probably one reason for this lack of research is that the Strontium sulfate exoskeleton of Acantharea is prone to dissolution which renders their enumeration in traps difficult; their contribution to sinking flux is usually underestimated.

\section{ECOSYSTEM MODELING}

Marine protists with acquired photosynthesis (except for Myrionecta rubra which is primarily a photoautotroph) are mixotrophs and generally fit the conceptual model for Type III mixotrophy (Photosynthetic 'Protozoa' that gain most of their carbon, nitrogen and phosphorous from ingestion of prey) (Stoecker 1998). Type III includes all the categories of acquired phototrophy illustrated in Fig. 2 with the possible exception of the 'obligate-obligate' category solely occupied by M. rubra. Type III mixotrophy has been considered in an idealized, steady state model of marine planktonic processes by Stickney et al. (2000). In this model, coexistence of mixotrophs with phytoplankton and zooplankton occurred, suggesting that mixotrophy represents a unique niche in the plankton even under summertime, quasi-steady-state conditions. This model also suggested that mixotrophy leads to decreased primary production based on uptake of dissolved inorganic nitrogen (new production) but that for mixotrophs which only feed on phytoplankton and other mixotrophs (e.g. plastidic oligotrichs) the total amount of photosynthesis, including that based on nitrogen from secondary sources, tends to increase. Essentially, the planktonic ecosystem becomes more efficient in terms of nitrogen because of nitrogen recycling within the mixotrophic cells.

In contrast to the Stickney model, Hammer \& Pitchford (2005) examined the Type III mixotrophy in a simplified model of predator-prey interactions. In their model, even low levels of Type III mixotrophy (a small fraction of the zooplankton being involved in primary production) had a stabilizing effect on the ecosystem by reducing the propensity for blooms while at the same time increasing overall productivity of the sys- 
tem. These results suggest that plastid retention among ciliates and other Type III mixotrophs (such as Rhizaria with endosymbionts) may increase stability as well as total primary and secondary production in planktonic food webs.

The lack of quantitative data on the effects of mixotrophy on GGE and trophic transfer, as well as the lack of basic information on the trophic level of both micrograzers and copepods, impedes realistic modeling of microbial food webs and their linkage to the metazoan food web. The example of photosynthesis meeting all or a substantial portion of respiratory demands for carbon in the plastid-retaining oligotrichs (Putt 1990b, Stoecker \& Michaels 1991) suggests that acquired phototrophy in other protists, including foraminifera, radiolaria and dinoflagellates, may also spare ingested carbon from respiration and thus potentially increase GGE. An increase in average protistan GGE in the euphotic zone could have substantial positive effects on secondary production and on transfer of carbon from the microbial food web to metazoan grazers (Landry \& Calbet 2004). This potential boost to food web efficiency has rarely been considered.

Acquired phototrophy (Type III mixotrophy) may have important roles in moderating ecosystem responses to perturbations such as increased stratification. Mainly because of the patchiness of the large protists bearing algal endosymbionts, their accurate impact on trophic transfer and incorporation in finer models is difficult to assess. This is particularly true for the colonial polycystines which may have one of the most significant impacts (Caron et al. 1995, Michaels et al. 1995, Dennett et al. 2002).

\section{ENVIRONMENTAL PERTURBATIONS}

Some protists with acquired phototrophy may be particularly susceptible to environmental perturbations. One very important group in ocean biogeochemistry and carbon flux, the Foraminifera, may be particularly vulnerable to ocean acidification because of their reliance on calcification (Russell et al. 2004, Fabry et al. 2008). In laboratory experiments, it has been shown that foraminifera shell mass decreases with decreases in seawater $\mathrm{pH}$ (Spero \& Parker 1985). Field observations of particular benthic foraminifera have demonstrated mottling and bleaching (Tagle et al. 1997) while other physiological perturbations have been observed in response to the current environmental changes and are likely to impact foraminifera communities in the near future (Hallock 2000). In tropical and subtropical pelagic ecosystems, shelled Foraminifera are particularly important in the flux of organic carbon out of surface waters and in the formation of cal- careous foraminiferan oozes that cover vast areas of the ocean floor (Kennish \& Lutz 1992). Benthic calcareous Foraminifera that depend on acquired phototrophy are important in carbonate deposition and reef building in shallow, warm seas (Lee 1998). The Foraminifera, Acantharea, and Radiolaria, important in carbon flux out of the mixed layer and biogeochemical cycling in oligotrophic waters, are all susceptible to increasing biologically damaging UVB and eutrophication, and may be negatively impacted by attempts at ocean fertilization to increase carbon sequestration.

\section{EVOLUTIONARY AND ECOLOGICAL ROLES OF 'EXCESS' CARBON FROM ACQUIRED PHOTOTROPHY}

Biological oceanographers and limnologists tend to focus on abiotic conditions and resource availability (bottom-up controls) in explaining the structure and function of aquatic ecosystems, but it is clear that species interactions are also important (Strom 2008). Net growth of populations and accumulation of biomass depend on the balance between growth and mortality. Adaptations that reduce mortality are hypothesized to have a large effect in 'reshaping' protistan communities and their roles in biogeochemical cycling and trophic transfer (Strom 2008).

It can be argued that acquired phototrophy has been important in supporting evolutionary innovation, including complex structural and behavioral adaptations that reduce mortality in aquatic protists. In most protists with acquired phototrophy, photosynthesis supplies carbon stoichiometrically in excess to nitrogen or phosphorous. Organisms have evolved fitnesspromoting purposes for 'excess carbon' such as energy/food storage (e.g. in mixotrophic ciliates), structures that reduce mortality due to predation (e.g. calcareous shells in Foraminifera, silicate tests of Polycystinea, polysaccharide plates covering mixotrophic oligotrichs, and gelatinous sheathes on some photosynthetic sessile ciliates), structures that increase food gathering capability and/or reduce sedimentation (e.g. spines on planktonic Foraminifera), and chemical as well as morphological defenses against predators (Hessen \& Anderson 2008).

An important adaptation that may rely on 'excess carbon' from photosynthesis is rapid movement (Crawford 1992, Dolan \& Perez 2000). All free-living ciliates are motile, but rapid movement in large ciliates with compound cilia (e.g. oligotrichs) is calculated to be energetically costly, perhaps requiring $42 \%$ of basal respiration (Crawford 1992). Some photosynthetic ciliates swim rapidly for their size and undergo extensive vertical migration (e.g. Myrionecta rubra). Some cili- 
ates have rapid escape responses from predators (e.g. in M. rubra and some oligotrichs) (Crawford 1992, Dolan \& Perez 2000). Rapid swimming may also allow exploitation of habitats with low prey concentrations because it should increase maximum clearance rates and, at low food concentrations, facilitate dispersal into new food patches.

\section{CONCLUSIONS}

Acquired phototrophy is at the root of much of the beauty and diversity that we observe among large aquatic protists, for example, the golden radiolarians, the green ciliates and the structurally complex shells of large benthic Foraminifera. Our understanding of how this diversity in form and function influences trophic dynamics and biogeochemical cycles in most aquatic ecosystems is rudimentary, but it is clear that we have to go beyond traditional classifications of aquatic protists as 'phyto' or 'zoo' and alter our concepts of 'trophic levels' to progress in our understanding of aquatic microbial ecology. This is a rich area for exploration using a combination of classical and molecular techniques, laboratory and field research and modeling.

Acknowledgements. We are honored to contribute to this Special Issue of AME honoring F. Rassoulzadegan who has contributed to our knowledge of acquired phototrophy in the sea as well as to many other areas of aquatic microbial ecology. D.K.S. thanks J. Dolan for the invitation to submit an article to this Special Issue. We thank M. Macek and several anonymous reviewers for their helpful comments which improved the manuscript. F.N. and C.dV were supported by a SAD grant SYMFORAD from the Région Bretagne (France) and the BioMarKs project funded by the European ERA-net program BiodivERsA.

\section{LITERATURE CITED}

Al-Qassab S, Lee WJ, Murray S, Simpson AGB, Patterson DJ (2002) Flagellates from stromatolites and surrounding sediments in Shark Bay, Western Australia. Acta Protozool 41: 91-144

Amblard C, Simengando T, Rachiq S, Bourdier G (1993) Importance of ciliated protozoa in relation to the bacterial and phytoplanktonic biomass in an oligo-mesotrophic lake, during the spring diatom bloom. Aquat Sci 55:1-9

Anderson OR (1983a) The radiolarian symbiosis. In: Goff L (ed) Algal symbiosis: a continuum of interaction strategies. Cambridge University Press, Cambridge, p 69-89

Anderson OR (1983b) Radiolaria. Springer-Verlag, Heidelberg

Anderson OR, Bé AWH (1976) The ultrastructure of a planktonic foraminifer, Globigerinoides sacculifer (Brady) and its symbiotic dinoflagellates. J Foraminiferal Res 6:1-21

Anderson OR, Matsuoka A (1992) Endocytoplasmic microalgae and bacteroids within the central capsule of the radiolarian Dictyocoryne truncatum. Symbiosis 12:237-247

Anderson OR, Swanberg NR, Bennett P (1983) Fine-structure of yellow-brown symbionts (Prymnesiida) in solitary radi- olaria and their comparison with similar acantharian symbionts. J Protozool 30:718-722

Auer B, Czioska E, Arndt H (2004) The pelagic community of a gravel pit lake: significance of Coleps hirtus viridis (Prostomatida) and its role as a scavenger. Limnologica 34: 187-198

Balech E (1967) Dinoflagelados nuevos o interesantes del Golfo de Mexico y Caribe. Rev Mus Argent Cienc Nat Bernardino Rivadavia Inst Nac Invest Cienc Nat (Argent). Hydrobiología 2:77-126

> Bé AWH, Spero HJ, Anderson OR (1982) Effects of symbiont elimination and reinfection on the life processes of the planktonic foraminifer Globigerinoides sacculifer. Mar Biol 70:73-86

Bé AWH, Tolderlund DS (1971) Distribution and ecology of living planktonic foraminifera in surface waters of the Atlantic and Indian Oceans. In: Funnell BM, Riedel WR (eds) The micropaleontology of oceans. Cambridge University Press, Cambridge, p 105-149

> Beaver JR, Crisman TL (1989a) Analysis of the community structure of planktonic ciliated protozoa relative to trophic state in Florida Lakes. Hydrobiologia 174:177-184

> Beaver JR, Crisman TL (1989b) The role of ciliated protozoa in pelagic freshwater ecosystems. Microb Ecol 17:111-136

Beers JR, Stewart GL (1970) The preservation of acantharians in fixed plankton samples. Limnol Oceanogr 15: $825-827$

Beers JR, Reid MH, Stewart GL (1975) Microplankton of the North Pacific gyre. Poupulation structure and abundance, June 1973. Int Rev Gesamten Hydrobiol 60:607-638

Bell EN, Laybourn-Parry J (1999) Annual plankton dynamics in an Antarctic saline lake. Freshw Biol 41:507-519

Bernard C, Rassoulzadegan F (1994) Seasonal variations of mixotrophic ciliates in the northwest Mediterranean Sea. Mar Ecol Prog Ser 108:295-301

> Bernhard JM (2003) Potential symbionts in bathyal Foraminifera. Science 299:861

Bernhard JM, Bowser SS (1999) Benthic foraminifera of dysoxic sediments: chloroplast sequestration and functional morphology. Earth Sci Rev 46:149-165

Berninger UG, Finlay BJ, Canter HM (1986) The spatialdistribution and ecology of zoochlorellae-bearing ciliates in a productive pond. J Protozool 33:557-563

Bernstein RE, Betzer PR, Feely RA, Byrne RH, Lamb MF, Michaels AF (1987) Acantharian fluxes and strontium to chlorinity ratios in the North Pacific Ocean. Science 237:1490-1494

Bienert RW, Beaver JR, Crisman TL (1991) The contribution of ciliated protozoa to zooplankton biomass in an acidic, subtropical lake. J Protozool 38:352-354

Bishop JKB (1988) The barite-opal-organic carbon association in oceanic particulate matter. Nature 332:341-343

> Bishop JKB, Edmond JM, Ketten DR, Bacon MP, Silker WB (1977) The chemistry, biology, and vertical flux of particulate matter from the upper $400 \mathrm{~m}$ of the equatorial Atlantic Ocean. Deep-Sea Res 24:511-548

> Bishop JKB, Ketten DR, Edmond JM (1978) The chemistry, biology and vertical flux of particulate matter from the upper $400 \mathrm{~m}$ of the Cape Basin in the southeast Atlantic Ocean. Deep-Sea Res 25:1121-1161

> Booth BC, Lewin J, Postel JR (1993) Temporal variation in the structure of autotrophic and heterotrophic communities in the Sub-Arctic Pacific. Prog Oceanogr 32:57-99

> Bowen HJM (1956) Strontium and barium in sea water and marine organisms. J Mar Biol Assoc UK 35:451-460

> Bulit C, Díaz-Ávalos C, Montagnes DJS (2004) Assessing spatial and temporal patchiness of the autotrophic ciliate 
Myrionecta rubra: a case study in a coastal lagoon. Mar Ecol Prog Ser 268:55-67

Burkholder JM, Glasgow HB (1997) Pfiesteria piscicida and other Pfiesteria-like dinoflagellates: behavior, impacts, and environmental controls. Limnol Oceanogr 42: 1052-1075

Burki F, Shalchian-Tabrizi K, Pawlowski J (2008) Phylogenomics reveals a new 'megagroup' including most photosynthetic eukaryotes. Biol Lett 4:366-369

Calado AJ, Moestrup Ø (2005) On the freshwater dinoflagellates presently included in the genus Amphidinium, with a description of Prosoaulax gen. nov. Phycologia 44:112-119

Calbet A, Saiz E (2005) The ciliate-copepod link in marine ecosystems. Aquat Microb Ecol 38:157-167

Caron DA, Bé AWH, Anderson OR (1982) Effects of variations in light intensity on life processes of the planktonic foraminifer Globigerinoides sacculifer in laboratory culture. J Mar Biol Assoc UK 62:435-451

> Caron DA, Michaels AF, Swanberg NR, Howse FA (1995) Primary productivity by symbiont-bearing planktonic sarcodines (Acantharia, Radiolaria, Foraminifera) in surface waters near Bermuda. J Plankton Res 17:103-129

> Caroppo C (2001) Autoecology and morphological variability of Dinophysis sacculus (Dinophyceae: Dinophysiaceae) in a Mediterranean lagoon. J Mar Biol Assoc UK 81:11-21

Carpenter EJ, Janson S, Boje R, Pollehne F, Chang J (1995) The Dinoflagellate Dinophysis norvegica: biological and ecological observations in the Baltic Sea. Eur J Phycol 30:1-9

Carrias JF, Amblard C, Bourdier G (1998) Seasonal dynamics and vertical distribution of planktonic ciliates and their relationship to microbial food resources in the oligomesotrophic Lake Pavin. Arch Hydrobiol 143:227-255

Carver CE, Mallet al. Warnock R, Douglas D (1996) Redcoloured digestive glands in cultured mussels and scallops: the implication of Mesodinium rubrum. J Shellfish Res 15:191-201

Castellani C, Irigoien X, Harris RP, Lampitt RS (2005) Feeding and egg production of Oithona similis in the North Atlantic. Mar Ecol Prog Ser 288:173-182

> Chesnick JM, Kooistra WHCF, Wellbrock U, Medlin LK (1997) Ribosomal RNA analysis indicates a benthic pennate diatom ancestry for the endosymbionts of the dinoflagellates Peridinium foliaceum and Peridinium balticum (Pyrrhophyta). J Eukaryot Microbiol 44:314-320

Chiang KP, Lin CY, Lee CH, Shiah FK, Chang J (2003) The coupling of oligotrich ciliate populations and hydrography in the East China Sea: spatial and temporal variations. Deep-Sea Res II 50:1279-1293

Christaki U, Obernosterer I, Van Wambeke F, Veldhuis M, Garcia N, Catala P (2008) Microbial food web structure in a naturally iron-fertilized area in the Southern Ocean (Kerguelen Plateau). Deep-Sea Res II 55:706-719

Cloern JE, Cole BE, Hager SW (1994) Notes on a Mesodinium rubrum red tide in San Francisco Bay (California, USA). J Plankton Res 16:1269-1276

Correia MJ, Lee JJ (2002) Fine structure of the plastids retained by the foraminifer Elphidium excavatum (Terquem). Symbiosis 32:27-38

Cota GF, Smith WO, Mitchell BG (1994) Photosynthesis of Phaeocystis in the Greenland Sea. Limnol Oceanogr 39:948-953

- Crawford DW (1989) Mesodinium rubrum: the phytoplankter that wasn't. Mar Ecol Prog Ser 58:161-174

Crawford DW (1992) Metabolic cost of motility in planktonic protists: theoretical considerations on size scaling and swimming speed. Microb Ecol 24:1-10
Crawford DW, Lindholm T (1997) Some observations on vertical distribution and migration of the phototrophic ciliate Mesodinium rubrum (= Myrionecta rubra) in a stratified brackish inlet. Aquat Microb Ecol 13:267-274

> Crawford DW, Stoecker DK (1996) Carbon content, dark respiration and mortality of the mixotrophic planktonic ciliate Strombidium capitatum. Mar Biol 126:415-422

Crawford DW, Purdie DA, Lockwood APM, Weissman P (1997) Recurrent red-tides in the Southampton Water estuary caused by the phototrophic ciliate Mesodinium rubrum. Estuar Coast Shelf Sci 45:799-812

> Daan R (1987) Impact of egg predation by Noctiluca miliaris on the summer development of copepod populations in the southern North Sea. Mar Ecol Prog Ser 37:9-17

de Vargas C, Norris R, Zaninetti L, Gibb SW, Pawlowski J (1999) Molecular evidence of cryptic speciation in planktonic foraminifers and their relation to oceanic provinces. Proc Natl Acad Sci USA 96:2864-2868

Dehairs F, Jacquet S, Savoye N, Van Mooy BAS and others (2008) Barium in twilight zone suspended matter as a potential proxy for particulate organic carbon remineralization: results for the North Pacific. Deep-Sea Res II 55: 1673-1683

Delwiche CF (1999) Tracing the thread of plastid diversity through the tapestry of life. Am Nat 154:S164-S177

Dennett MR, Caron DA, Michaels AF, Gallager SM, Davis GS (2002) Video plankton recorder reveals high abundances of colonial Radiolarians in surface waters of the central North Pacific. J Plankton Res 24:797-805

Dolan J (1992) Mixotrophy in ciliates: a review of Chlorella symbiosis and chloroplast retention. Mar Microb Food Webs 6:115-132

Dolan JR, Marrase C (1995) Planktonic ciliate distribution relative to a deep chlorophyll maximum: Catalan sea, NW Mediterranean, June 1993. Deep-Sea Res I 42:1965-1987

> Dolan JR, Perez MT (2000) Costs, benefits and characteristics of mixotrophy in marine oligotrichs. Freshw Biol 45:227-238

> Dolven JK, Lindqvist C, Albert VA, Bjorklund KR, Yuasa T, Takahashi O, Mayama S (2007) Molecular diversity of alveolates associated with neritic north Atlantic Radiolarians. Protist 158:65-76

> Drebes G, Schnepf E (1988) Paulsenella Chatton (Dinophyta), ectoparasites of marine diatoms: development and taxonomy. Helgol Meersunters 42:563-581

Dugdale RC, Wilkerson FP, Barber RT, Blasco D, Packard TT (1987) Changes in nutrients, $\mathrm{pH}$, light penetration and heat budget by migrating photosynthetic organisms. Oceanol Acta S6:103-107

Duguay LE, Taylor DL (1978) Primary production and calcification by the soritid foraminifer Archaias (Fitchel and Moll). J Protozool 25:356-361

Eashwar M, Nallathambi T, Kuberaraj K, Govindarajan G (2001) Noctiluca blooms in Port Blair Bay, Andamans. Curr Sci 81:203-206

> Erez J (1978) Vital effect on stable-isotope composition seen in foraminifera and coral skeletons. Nature 273:199-202

Eriksen NT, Hayes KC, Lewitus AJ (2002) Growth responses of the mixotrophic dinoflagellates, Cryptoperidiniopsis sp. and Pfiesteria piscicida, to light under prey-saturated conditions. Harmful Algae 1:191-203

- Fabry VJ, Seibel BA, Feely RA, Orr JC (2008) Impacts of ocean acidification on marine fauna and ecosystem processes. ICES J Mar Sci 65:414-432

Falkowski PG, Katz ME, Knoll AH, Quigg A, Raven JA, Schofield O, Taylor FJR (2004) The evolution of modern eukaryotic phytoplankton. Science 305:354-360 
Farmer MA, Roberts KR (1990) Organelle Loss in the Endosymbiont of Gymnodinium acidotum (Dinophyceae). Protoplasma 153:178-185

Febvre J, Febvre-Chevalier C (1979) Ultrastructural study of zooxanthellae of 3 species of Acantharia (Protozoa: Actinopoda), with details of their taxonomic position in the Prymnesiales (Prymnesiophyceae Hibberd, 1976). J Mar Biol Assoc UK 59:215-226

Fehling J, Stoecker D, Baldauf SL (2007) Photosynthesis and the eukaryote tree of life. In: Falkowski PG, Knoll AH (eds) Evolution of primary producers in the sea. Academic Press, Elsevier, New York, p 76-107

Feinstein TN, Traslavina R, Sun MY, Lin SJ (2002) Effects of light on photosynthesis, grazing, and population dynamics of the heterotrophic dinoflagellate Pfiesteria piscicida (Dinophyceae). J Phycol 38:659-669

Fenchel T, Hansen PJ (2006) Motile behaviour of the bloomforming ciliate Mesodinium rubrum. Mar Biol Res 2:33-40

Fields SD, Rhodes RG (1991) Ingestion and retention of Chroomonas spp. (Cryptophyceae) by Gymnodinium acidotum (Dinophyceae). J Phycol 27:525-529

Finlay BJ, Maberly SC, Esteban GF (1996) Spectacular abundance of ciliates in anoxic pond water: contribution of symbiont photosynthesis to host respiratory oxygen requirements. FEMS Microbiol Ecol 20:229-235

Foissner W, Berger H, Schaumburg J (1999) Identification and ecology of limnetic plankton ciliates. Bavarian State Office for Water Management, Munich

France J, Mozetiã P (2006) Ecological characterization of toxic phytoplankton species (Dinophysis spp., Dinophyceae) in Slovenian mariculture areas (Gulf of Trieste, Adriatic Sea) and the implications for monitoring. Mar Pollut Bull 52:1504-1516

Froneman PW, Perissinotto R (1996) Microzooplankton grazing and protozooplankton community structure in the South Atlantic and in the Atlantic sector of the Southern Ocean. Deep-Sea Res I 43:703-721

Furuya K, Saito H, Sriwoon R, Omura T, Furio EE, Borja VM, Lirdwitayaprasit T (2006) Vegetative growth of Noctiluca scintillans containing the endosymbiont Pedinomonas noctilucae. Afr J Mar Sci 28:305-308

> Garçes E, Delgado M, Camp J (1997) Phased cell division in a natural population of Dinophysis sacculus and the in situ measurement of potential growth rate. J Plankton Res 19: 2067-2077

- Gast RJ, Caron DA (1996) Molecular phylogeny of symbiotic dinoflagellates from planktonic foraminifera and radiolaria. Mol Biol Evol 13:1192-1197

Gast RJ, Caron DA (2001) Photosymbiotic associations in planktonic foraminifera and radiolaria. Hydrobiologia 461: $1-7$

Gast RJ, McDonnell TA, Caron DA (2000) srDNA-based taxonomic affinities of algal symbionts from a planktonic foraminifer and a solitary radiolarian. J Phycol 36:172-177

Gast RJ, Moran DM, Dennett MR, Caron DA (2007) Kleptoplasty in an Antarctic dinoflagellate: Caught in evolutionary transition? Environ Microbiol 9:39-45

Godhe A, Svensson S, Rehnstam-Holm AS (2002) Oceanographic settings explain fluctuations in Dinophysis spp. and concentrations of diarrhetic shellfish toxin in the plankton community within a mussel farm area on the Swedish west coast. Mar Ecol Prog Ser 240:71-83

Goldman JC (1988) Spatial and temporal discontinuities of biological processes in pelagic surface waters. In: Rothschild BJ (ed) Toward a theory on biological-physical interactions in the World Ocean. Kluwer Academic Publishers, Dordrecht, p 273-296
Gómez F (2003) Checklist of Mediterranean free-living dinoflagellates. Bot Mar 46:215-242

Gómez F (2007) Trends on the distribution of ciliates in the open Pacific Ocean. Acta Oecol 32:188-202

> Gowing MM, Garrison DL (1992) Abundance and feeding ecology of larger protozooplankton in the ice edge zone of the Weddell and Scotia Seas during the austral winter. Deep-Sea Res A 39:893-919

Graham LB, Colburn AD, Burke JC (1976) A new simple method for gently collecting planktonic protozoa. Limnol Oceanogr 21:336-340

Grzebyk D, Schofield O, Vetriani C, Falkowski PG (2003) The mesozoic radiation of eukaryotic algae: the portable plastid hypothesis. J Phycol 39:259-267

Grzymski J, Schofield OM, Falkowski PG (2002) The function of plastids in the deep-sea benthic foraminifer, Nonionella stella. Limnol Oceanogr 47:1569-1580

Gustafson DE, Stoecker DK, Johnson MD, Van Heukelem WF, Sneider K (2000) Cryptophyte algae are robbed of their organelles by the marine ciliate Mesodinium rubrum. Nature 405:1049-1052

Hackett JD, Maranda L, Yoon HS, Bhattacharya D (2003) Phylogenetic evidence for the cryptophyte origin of the plastid of Dinophysis (Dinophysiales, Dinophyceae). J Phycol 39: 440-448

Hallegraeff GM, Lucas IAN (1988) The marine dinoflagellate genus Dinophysis (Dinophyceae)—photosynthetic, neritic and non-photosynthetic, oceanic species. Phycologia 27: $25-42$

Hallock P (2000) Symbiont-bearing foraminifera: Harbingers of global change? Mar Micropaleontol 46:95-104

Hallock Muller P (1976) Sediment production by shallowwater benthic foraminifera at selected sites around Oahu, Hawaii. Marit Sediments 1:263-265

Hammer AC, Pitchford JW (2005) The role of mixotrophy in plankton bloom dynamics, and the consequences for productivity. ICES J Mar Sci 62:833-840

Hansen PJ, Fenchel T (2006) The bloom-forming ciliate Mesodinium rubrum harbours a single permanent endosymbiont. Mar Biol Res 2:169-177

> Hansen PJ, Miranda L, Azanza R (2004) Green Noctiluca scintillans: a dinoflagellate with its own greenhouse. Mar Ecol Prog Ser 275:79-87

Hecky RE, Kling HJ (1981) The phytoplankton and proto-zooplankton of the euphotic zone of Lake Tanganyika-species composition, biomass, chlorophyll content, and spatio-temporal distribution. Limnol Oceanogr 26:548-564

Hemleben C, Spindler M, Anderson OR (1989) Modern planktonic foraminifera. Springer-Verlag, Berlin

Hessen DO, Anderson TR (2008) Excess carbon in aquatic organisms and ecosystems: physiological, ecological, and evolutionary implications. Limnol Oceanogr 53:1685-1696

Hibberd DJ (1977) Ultrastructure of the cryptomonad endosymbiont of the red-water ciliate Mesodinium rubrum. J Mar Biol Assoc UK 57:45-61

Holen DA (2000) The relative abundance of mixotrophic and heterotrophic ciliates in an oligotrophic lake. Arch Hydrobiol 150:1-15

> Holzmann M, Habura A, Giles H, Bowser SS, Pawlowski J (2003) Freshwater foraminiferans revealed by analysis of environmental DNA samples. J Eukaryot Microbiol 50: 135-139

Horiguchi T, Pienaar RN (1992) Amphidinium latum Lebour (Dinophyceae), a sand-dwelling dinoflagellate feeding on cryptomonads. Jap J Phycol 40:353-363

> Horiguchi T, Takano Y (2006) Serial replacement of a diatom endosymbiont in the marine dinoflagellate Peridinium 
quinquecorne (Peridiniales, Dinophyceae). Phycol Res 54: 193-200

Horstman DA (1981) Reported red-water outbreaks and their effects on fauna of the west and south coasts of South Africa, 1959-1980. Fish Bull 15:71-88

Inagaki Y, Dacks JB, Doolittle WF, Watanabe KI, Ohama T (2000) Evolutionary relationship between dinoflagellates bearing obligate diatom endosymbionts: insight into tertiary endosymbiosis. Int $\mathrm{J}$ Syst Evol Microbiol 50: 2075-2081

Jacobson DM, Andersen RA (1994) The discovery of mixotrophy in photosynthetic species of Dinophysis (Dinophyceae)-light and electron-microscopic observations of food vacuoles in Dinophysis acuminata, D. norvegica and 2 heterotrophic dinophysoid dinoflagellates. Phycologia 33:97-110

Jakobsen HH, Hansen PJ, Larsen J (2000) Growth and grazing responses of two chloroplast-retaining dinoflagellates: effect of irradiance and prey species. Mar Ecol Prog Ser 201:121-128

Johnson MD, Stoecker DK (2005) Role of feeding in growth and photophysiology of Myrionecta rubra. Aquat Microb Ecol 39:303-312

Johnson PW, Donaghay PL, Small EB, Sieburth JM (1995) Ultrastructure and ecology of Perispira ovum (Ciliophora: Litostomatea): an aerobic, planktonic ciliate that sequesters the chloroplasts, mitochondria, and paramylon of Euglena proxima in a micro-oxic habitat. J Eukaryot Microbiol 42:323-335

> Johnson MD, Tengs T, Oldach D, Stoecker DK (2006) Sequestration, performance, and functional control of cryptophyte plastids in the ciliate Myrionecta rubra (Ciliophora). J Phycol 42:1235-1246

Johnson MD, Oldach D, Delwiche CF, Stoecker DK (2007) Retention of transcriptionally active cryptophyte nuclei by the ciliate Myrionecta rubra. Nature 445:426-428

Jones RI (1994) Mixotrophy in planktonic protists as a spectrum of nutritional strategies. Mar Microb Food Webs 8:87-96

Jonsson PR (1987) Photosynthetic assimilation of inorganic carbon in marine oligotrich ciliates (Ciliophora, Oligotrichina). Mar Microb Food Webs 2:55-68

Kamiyama T, Arima S, Tsujino M (2003) Characteristics of the distribution of bacteria, heterotrophic nanoflagellates and ciliates in Hiroshima Bay in summer. Fish Sci 69:755-766

Karakashian SJ (1963) Growth of Paramecium bursaria as influenced by the presence of algal symbionts. Physiol Zool 36:52-68

Keeling PJ (2009) Chromalveolates and the evolution of plastids by secondary endosymbiosis. J Eukaryot Microbiol 56:1-8

Kempton JW, Wolny J, Tengs T, Rizzo P and others (2002) Kryptoperidinium foliaceum blooms in South Carolina: a multi-analytical approach to identification. Harmful Algae $1: 383-392$

Kennish MJ, Lutz RA (1992) Calcium-carbonate in surface sediments of the deep ocean floor. Rev Aquat Sci 6: 183-202

Khmeleva NN (1967) Role of the radiolarians in the value of primary productivity in the Red Sea and Gulf of Aden. Dokl Akad Nauk SSSR 172:1430-1433

Klöpper S, Scharek R, Gerdts G (2003) Diarrhetic shellfish toxicity in relation to the abundance of Dinophysis spp. in the German Bight near Helgoland. Mar Ecol Prog Ser 259:93-102

Koike K, Takishita K (2008) Anucleated cryptophyte vestiges in the gonyaulacalean dinoflagellates Amylax buxus and Amylax triacantha (Dinophyceae). Phycol Res 56:301-311
Koike K, Sekiguchi H, Kobiyama A, Takishita K, Kawachi M, Ogata T (2005) A novel type of kleptoplastidy in Dinophysis (Dinophyceae): presence of haptophyte-type plastid in Dinophysis mitra. Protist 156:225-237

Koike K, Nishiyama A, Takishita K, Kobiyama A, Ogata T (2007) Appearance of Dinophysis fortii following blooms of certain cryptophyte species. Mar Ecol Prog Ser 337: 303-309

Koukaras K, Nikolaidis G (2004) Dinophysis blooms in Greek coastal waters (Thermaikos Gulf, NW Aegean Sea). J Plankton Res 26:445-457

Kunitmoo Y, Sarashina I, Iijima M, Endo K, Sashida K (2006) Molecular phylogeny of acantharian and polycystine radiolarians based on ribosomal DNA sequences, and some comparisons with data from the fossil record. Eur J Protistol 42:143-153

Landry MR, Calbet A (2004) Microzooplankton production in the oceans. ICES J Mar Sci 61:501-507

Lane CE, Archibald JM (2008) The eukaryotic tree of life: endosymbiosis takes its TOL. Trends Ecol Evol 23:268-275

Langer MR (2008) Assessing the contribution of foraminiferan protists to global ocean carbonate production. J Eukaryot Microbiol 55:163-169

Larsen J (1988) An ultrastructural study of Amphidinium poecilochroum (Dinophyceae), a phagotrophic dinoflagellate feeding on small species of cryptophytes. Phycologia 27: 366-377

Laval-Peuto M, Febvre Ma M (1986) On plastid symbiosis in Tontonia appendiculariformis. Biosystems 19:137-157

Laval-Peuto M, Rassoulzadegan F (1988) Autofluorescence of marine planktonic oligotrichina and other ciliates. Hydrobiologia 159:99-110

Laybourn-Parry J (2002) Survival mechanisms in Antarctic lakes. Philos Trans R Soc Lond B 357:863-869

Laybourn-Parry J, Rogerson A (1993) Seasonal patterns of protozooplankton in Lake Windermere, England. Arch Hydrobiol 129:25-43

Laybourn-Parry J, Marchant HJ, Brown P (1991) The plankton of a large oligotrophic freshwater Antarctic lake. J Plankton Res 13:1137-1149

Laybourn-Parry J, Perriss SJ, Seaton GGR, Rohozinski J (1997) A mixotrophic ciliate as a major contributor to plankton photosynthesis in Australian lakes. Limnol Oceanogr 42:1463-1467

Lee JJ (1990) Fine structure of the rhodophycean of Porphyridium purpureum in situ in Peneropolis pertusus (Forskal) and $P$. acicularis (Batsch) and in axenic culture. J Foraminiferal Res 20:162-169

Lee JJ (1998) 'Living sands' - larger foraminifera and their endosymbiotic algae. Symbiosis 25:71-100

Lee JJ (2006) Algal symbiosis in larger foraminifera. Symbiosis 42:63-75

Lee JJ, McEnery ME (1983) Symbiosis in foraminifera. In: Goff L (ed) Algal symbiosis: a continuum of interaction strategies. Cambridge University Press, Cambridge, p 37-68

> Lee JJ, Morales J, Symons A, Hallock P (1995) Diatom symbionts in larger foraminifera from Caribbean hosts. Mar Micropaleontol 26:99-105

Lee JJ, Morales J, Bacus S, Diamont A, Hallock P, Pawlowski J, Thorpe J (1997) Progress in characterizing the endosymbiotic dinoflagellates of soritid foraminifera and related studies on some stages of the life cycle of Marginopora vertebralis. J Foraminiferal Res 27:254-263

Lee JS, Igarashi T, Fraga S, Dahl E, Hovgaard P, Yasumoto T (1989) Determination of diarrhetic shellfish toxins in various dinoflagellate species. J Appl Phycol 1:147-152 
Leppänen JM, Bruun JE (1986) The role of pelagic ciliates including the autotrophic Mesodinium rubrum during the spring bloom of 1982 in the open northern Baltic proper. Ophelia 4:147-157

Levinsen H, Nielsen TG (2002) The trophic role of marine pelagic ciliates and heterotrophic dinoflagellates in arctic and temperate coastal ecosystems: a cross-latitude comparison. Limnol Oceanogr 47:427-439

Levinsen H, Nielsen TG, Hansen BW (1999) Plankton community structure and carbon cycling on the western coast of Greenland during the stratified summer situation. II. Heterotrophic dinoflagellates and ciliates. Aquat Microb Ecol 16:217-232

> Levinsen H, Nielsen TG, Hansen BW (2000) Annual succession of marine pelagic protozoans in Disko Bay, West Greenland, with emphasis on winter dynamics. Mar Ecol Prog Ser 206:119-134

Lewitus AJ, Glasgow HB, Burkholder JM (1999) Kleptoplastidy in the toxic dinoflagellate Pfiesteria piscicida (Dinophyceae). J Phycol 35:303-312

> Lewitus AJ, Wetz MS, Willis BM, Burkholder JM, Parrow MW, Glasgow HB (2006) Grazing activity of Pfiesteria piscicida (Dinophyceae) and susceptibility to ciliate predation vary with toxicity status. Harmful Algae 5:427-434

Lin SJ, Zhang H, Duboist A (2006) Low abundance distribution of Pfiesteria piscicida in Pacific and Western Atlantic as detected by mtDNA-18S rDNA real-time polymerase chain reaction. J Plankton Res 28:667-681

Lindholm T (1985) Mesodinium rubrum-a unique photosynthetic ciliate. Adv Aquat Microbiol 3:1-48

Lindholm T, Mörk AC (1990) Depth maxima of Mesodinium rubrum (Lohmann) Hamburger and Buddenbrockexamples from a stratified Baltic Sea inlet. Sarsia 75:53-64

Lindholm T, Lindroos P, Mörk AC (1988) Ultrastructure of the photosynthetic ciliate Mesodinium rubrum. Biosystems 21:141-149

> Lobban CS, Schefter M, Simpson AGB, Pochon X, Pawlowski J, Foissner W (2002) Maristentor dinoferus n. gen., n. sp., a giant heterotrich ciliate (Spirotrichea: Heterotrichida) with zooxanthellae, from coral reefs on Guam, Mariana Islands. Mar Biol 141:207-208

Lobban CS, Modeo L, Verni F, Rosati G (2005) Euplotes uncinatus (Ciliophora, Hypotrichia), a new species with zooxanthellae. Mar Biol 147:1055-1061

Lopez E (1979) Algal chloroplasts in the protoplasm of 3 species of benthic foraminifera: taxonomic affinity, viability, and persistence. Mar Biol 53:201-211

Lynn DH, Roff JC, Hopcroft RR (1991) Annual abundance and biomass of aloricate ciliates in tropical neritic waters of Kingston, Jamaica. Mar Biol 110:437-448

Macek M, Śimek K, Pernthaler J, Vyhnálek V, Psenner R (1996) Growth rates of dominant planktonic ciliates in two freshwater bodies of different trophic degree. J Plankton Res 18:463-481

- Macek M, Šimek K, Bittl T (2001) Conspicuous peak of oligotrichous ciliates following winter stratification in a bog lake. J Plankton Res 23:353-363

Macek M, Callieri C, Šimek K, Vazquez AL (2006) Seasonal dynamics, composition and feeding patterns of ciliate assemblages in oligotrophic lakes covering a wide $\mathrm{pH}$ range. Arch Hydrobiol 166:261-287

Macek M, Pestova D, Perez MEM (2008) Seasonal and spatial dynamics of a ciliate assemblage in a warm-monomictic Lake Alchichica (Puebla, Mexico). Hydrobiologia 18: 25-35

> Maneiro I, Frangópulos M, Guisande C, Fernández M, Reguera B, Riveiro I (2000) Zooplankton as a potential vector of diarrhetic shellfish poisoning toxins through the food web. Mar Ecol Prog Ser 201:155-163

Martin W, Herrmann RG (1998) Gene transfer from organelles to the nucleus: How much, what happens, and why? Plant Physiol 118:9-17

Martin AJ, Montagnes DJS (1993) Winter ciliates in a British Columbian Fjord: six new species and an analysis of ciliate putative prey. J Eukaryot Microbiol 40:535-549

McKee ED, Chronic J, Leopold EB (1959) Sedimentary belts in the lagoon of Kaparingamarangi Atoll. Am Assoc Pet Geol Bull 43:501-562

McManus GB, Zhang H, Lin SJ (2004) Marine planktonic ciliates that prey on macroalgae and enslave their chloroplasts. Limnol Oceanogr 49:308-313

McManus GB, Costas BA, Dam HG, Lopes RM, Gaeta SA, Susini SM, Rosetta CH (2007) Microzooplankton grazing of phytoplankton in a tropical upwelling region. Hydrobiologia 575:69-81

Michaels AF (1988) Vertical distribution and abundance of Acantharia and their symbionts. Mar Biol 97:559-569

Michaels AF (1991) Acantharian abundance and symbiont productivity at the vertex seasonal station. J Plankton Res 13:399-418

Michaels AF, Caron DA, Swanberg NR, Howse FA, Michaels CM (1995) Planktonic sarcodines (Acantharia, Radiolaria, Foraminifera) in surface waters near Bermuda: abundance, biomass and vertical flux. J Plankton Res 17:131-163

- Minnhagen S, Janson S (2006) Genetic analyses of Dinophysis spp. support kleptoplastidy. FEMS Microbiol Ecol $57: 47-54$

Modenutti BE, Balseiro EG (2002) Mixotrophic ciliates in an Andean lake: dependence on light and prey of an Ophrydium naumanni population. Freshw Biol 47:121-128

Modenutti BE, Balseiro EG, Callieri C, Bertoni R, Queimalinos CP (2005) Effect of UV-B and different PAR intensities on the primary production of the mixotrophic planktonic ciliate Stentor araucanus. Limnol Oceanogr 50:864-871

> Modigh M (2001) Seasonal variations of photosynthetic ciliates at a Mediterranean coastal site. Aquat Microb Ecol 23:163-175

> Montagnes DJS, Lynn DH (1989) The annual cycle of Mesodinium rubrum in the waters surrounding the Isles of Shoals, Gulf of Maine. J Plankton Res 11:193-201

Montagnes DJS, Poulton AJ, Shammon TM (1999) Mesoscale, finescale and microscale distribution of micro- and nanoplankton in the Irish Sea, with emphasis on ciliates and their prey. Mar Biol 134:167-179

> Montagnes DJS, Allen J, Brown L, Bulit C and others (2008) Factors controlling the abundance and size distribution of the phototrophic ciliate Myrionecta rubra in open waters of the North Atlantic. J Eukaryot Microbiol 55:457-465

> Müller H, Schone A, Pintocoelho RM, Schweizer A, Weisse T (1991) Seasonal succession of ciliates in Lake Constance. Microb Ecol 21:119-138

> Myung G, Yih W, Kim HS, Park JS, Cho BC (2006) Ingestion of bacterial cells by the marine photosynthetic ciliate Myrionecta rubra. Aquat Microb Ecol 44:175-180

Nagai S, Nitshitani G, Tomaru Y, Sakiyama S, Kamiyama T (2008) Predation by the toxic dinoflagellate Dinophysis fortii on the ciliate Myrionecta rubra and observation of sequestration of ciliate chloroplasts. J Phycol 44: 909-922

Norris RD (1996) Symbiosis as an evolutionary innovation in the radiation of paleocene planktic foraminifera. Paleobiology 22:461-480

Oakley BR, Taylor FJR (1978) Evidence for a new type of endosymbiotic organization in a population of the ciliate 
Mesodinium rubrum from British Columbia. Biosystems 10:361-369

Obolkina LA (2006) Planktonic ciliates of Lake Baikal. Hydrobiologia 568:193-199

> Okamoto N, Inouye I (2006) Hatena arenicola gen. et sp nov., a katablepharid undergoing probable plastid acquisition. Protist 157:401-419

Okolodkov YB, Dodge JD (1996) Biodiversity and biogeography of planktonic dinoflagellates in the Arctic Ocean. J Exp Mar Biol Ecol 202:19-27

Olli K (1999) Diel vertical migration of phytoplankton and heterotrophic flagellates in the Gulf of Riga. J Mar Syst 23:145-163

Ota T, Taniguchi A (2003) Standing crop of planktonic ciliates in the East China Sea and their potential grazing impact and contribution to nutrient regeneration. Deep-Sea Res II 50:423-442

Owen RW, Gianesella-Galvão SF, Kutner MBB (1992) Discrete, subsurface layers of the autotrophic ciliate Mesodinium rubrum off Brazil. J Plankton Res 14:97-105

Pace ML (1982) Planktonic ciliates: their distribution, abundance, and relationship to microbial resources in a monomictic lake. Can J Fish Aquat Sci 39:1106-1116

Packard T, Blasco D, Barber R (1978) Mesodinium rubrum in the Baja California upwelling system. In: Boje R, Tomczak $\mathrm{M}$ (eds) Upwelling ecosystems. Springer-Verlag, Berlin, p 73-89

Park MG, Kim S, Kim HS, Myung G, Kang YG, Yih W (2006) First successful culture of the marine dinoflagellate Dinophysis acuminata. Aquat Microb Ecol 45:101-106

Park MG, Park JS, Kim M, Yih W (2008) Plastid dynamics during survival of Dinophysis caudata without its ciliate prey. J Phycol 44:1154-1163

Pawlowski J, Holzmann M, Fahrni JF, Hallock P (2001a) Molecular identification of algal endosymbionts in large miliolid foraminifera: 1. Chlorophytes. J Eukaryot Microbiol 48:362-367

Pawlowski J, Holzmann M, Fahrni JF, Pochon X, Lee JJ (2001b) Molecular identification of algal endosymbionts in large miliolid foraminifera: 2. Dinoflagellates. J Eukaryot Microbiol 48:368-373

Perez MT, Dolan JR, Vidussi F, Fukai E (2000) Diel vertical distribution of planktonic ciliates within the surface layer of the NW Mediterranean (May 1995). Deep-Sea Res I 47:479-503

Perriss SJ, Laybournparry J, Jones RI (1994) Chlorophyll contents and photosynthetic rates of the freshwater mixotrophic ciliate Strombidium viride (Ciliophora, Oligotrichida). Arch Hydrobiol 130:473-483

Peštová D, Macek M, Pérez MEM (2008) Ciliates and their picophytoplankton-feeding activity in a high-altitude warm-monomictic saline lake. Eur J Protistol 44:13-25

> Pienaar RN, Sakai H, Horiguchi T (2007) Description of a new dinoflagellate with a diatom endosymbiont, Durinskia capensis sp nov (Peridiniales, Dinophyceae) from South Africa. J Plant Res 120:247-258

> Pirlot S, Vanderheyden J, Descy JP, Servais P (2005) Abundance and biomass of heterotrophic microorganisms in Lake Tanganyika. Freshw Biol 50:1219-1232

Pitta P, Giannakourou A (2000) Planktonic ciliates in the oligotrophic Eastern Mediterranean: vertical, spatial distribution and mixotrophy. Mar Ecol Prog Ser 194: 269-282

Pitta P, Giannakourou A, Christaki U (2001) Planktonic ciliates in the oligotrophic Mediterranean Sea: longitudinal trends of standing stocks, distributions and analysis of food vacuole contents. Aquat Microb Ecol 24:297-311
Pochon X, Montoya-Burgos JI, Stadelmann B, Pawlowski J (2006) Molecular phylogeny, evolutionary rates, and divergence timing of the symbiotic dinoflagellate genus Symbiodinium. Mol Phylogenet Evol 38:20-30

Putt M (1990a) Abundance, chlorophyll content and photosynthetic rates of ciliates in the Nordic Seas during summer. Deep-Sea Res A 37:1713-1731

Putt M (1990b) Metabolism of photosynthate in the chloroplast-retaining ciliate Laboea strobila. Mar Ecol Prog Ser 60:271-282

Queimalinos CP, Modenutti BE, Balseiro EG (1999) Symbiotic association of the ciliate Ophrydium naumanni with Chlorella causing a deep chlorophyll a maximum in an oligotrophic South Andes lake. J Plankton Res 21:167-178

Quigg A, Finkel ZV, Irwin AJ, Rosenthal Y and others (2003) The evolutionary inheritance of elemental stoichiometry in marine phytoplankton. Nature 425:291-294

Raven JA (1997) Phagotrophy in phototrophs. Limnol Oceanogr 42:198-205

Reisser W (1986) Endosymbiotic associations of freshwater protozoa and algae. In: Corliss JO, Patterson DJ (eds) Progress in protistology, 1. Biopress, Bristol, p 195-214

> Rogerson A, Finlay BJ, Berninger UG (1989) Sequestered chloroplasts in the freshwater ciliate Strombidium viride (Ciliophora, Oligotrichida). Trans Am Microsc Soc 108: 117-126

> Russell AD, Honisch B, Spero HJ, Lea DW (2004) Effects of seawater carbonate ion concentration and temperature on shell $\mathrm{U}, \mathrm{Mg}$, and $\mathrm{Sr}$ in cultured planktonic foraminifera. Geochim Cosmochim Acta 68:4347-4361

Sahayak S, Jyothibabu R, Jayalakshmi KJ, Habeebrehman H and others (2005) Red tide of Noctiluca miliaris off south of Thiruvananthapuram subsequent to the 'stench event' at the southern Kerala coast. Curr Sci 89:1472-1473

Sanchez-Puerta MV, Delwiche CF (2008) A hypothesis for plastid evolution in chromalveolates. J Phycol 44: 1097-1107

Sanders RW (1995) Seasonal distributions of the photosynthesizing ciliates Laboea strobila and Myrionecta rubra (=Mesodinium rubrum) in an estuary of the Gulf of Maine. Aquat Microb Ecol 9:237-242

Schweiker M, Elbrächter M (2004) First ultrastructural investigations of the consortium between a phototrophic eukaryotic endocytobiont and Podolampas bipes (Dinophyceae). Phycologia 43:614-623

Setälä O, Kivi K (2003) Planktonic ciliates in the Baltic Sea in summer: distribution, species association and estimated grazing impact. Aquat Microb Ecol 32:287-297

Shaked Y, de Vargas C (2006) Pelagic photosynthesis: rDNA assessment of diversity and evolution of dinoflagellate symbionts and planktonic foraminiferal hosts. Mar Ecol Prog Ser 325:59-71

Sieracki ME, Verity PG, Stoecker DK (1993) Plankton community response to sequential silicate and nitrate depletion during the 1989 North-Atlantic spring bloom. Deep-Sea Res II 40:213-225

Silver MW, Gowing MM (1991) The 'particle' flux: origins and biological components. Prog Oceanogr 26:75-113

> Sime-Ngando T, Juniper K, Vézina A (1992) Ciliated protozoan communities over cobb seamount: increase in biomass and spatial patchiness. Mar Ecol Prog Ser 89: $37-51$

> Šimek K, Macek M, Pernthaler J, Straskrabová V, Psenner R (1996) Can freshwater planktonic ciliates survive on a diet of picoplankton? J Plankton Res 18:597-613

> Skovgaard A (1998) Role of chloroplast retention in a marine dinoflagellate. Aquat Microb Ecol 15:293-301 
Smith M, Hansen PJ (2007) Interaction between Mesodinium rubrum and its prey: importance of prey concentration, irradiance and $\mathrm{pH}$. Mar Ecol Prog Ser 338:61-70

Smith WO, Barber RT (1979) Carbon budget for the autotrophic ciliate Mesodinium rubrum. J Phycol 15:27-33

Sommaruga R, Psenner R (1995) Trophic interactions within the microbial food-web in Piburger-See (Austria). Arch Hydrobiol 132:257-278

Sommaruga R, Whitehead K, Shick JM, Lobban CS (2006) Mycosporine-like amino acids in the zooxanthella-ciliate symbiosis Maristentor dinoferus. Protist 157:185-191

Sonntag B, Posch T, Klammer S, Teubner K, Psenner R (2006) Phagotrophic ciliates and flagellates in an oligotrophic, deep, alpine lake: contrasting variability with seasons and depths. Aquat Microb Ecol 43:193-207

Sorokin YI, Kogelshatz J (1979) Analysis of heterotrophic microplankton in an upwelling area. Hydrobiologia 66: 195-208

Sorokin YI, Sorokin PY, Mamaeva TI (1996) Density and distribution of bacterioplankton and planktonic ciliates in the Bering Sea and North Pacific. J Plankton Res 18:1-16

Sournia A (1976) Primary production of sands in the lagoon of an atoll and the role of foraminiferan symbionts. Mar Biol 37:29-32

Spero HJ, Parker SL (1985) Photosynthesis in the symbiotic planktonic foraminifer Orbulina universa and its potential contribution to oceanic primary productivity. J Foraminiferal Res 15:273-281

Sriwoon R, Pholpunthin P, Lirdwitayaprasit T, Kishino M, Furuya K (2008) Population dynamics of green Noctiluca scintillans (Dinophyceae) associated with the monsoon cycle in the upper Gulf of Thailand. J Phycol 44:605-615

Steineck PL, Casey RE (1990) Ecology and paleobiology of Foraminifera and Radiolaria. In: Capriulo GM (ed) Ecology of marine protozoa. Oxford University Press, New York, p 46-138

Stickney HL, Hood RR, Stoecker DK (2000) The impact of mixotrophy on planktonic marine ecosystems. Ecol Model 125:203-230

Stoecker DK (1998) Conceptual models of mixotrophy in planktonic protists and some ecological and evolutionary implications. Eur J Protistol 34:281-290

Stoecker DK (1999) Mixotrophy among dinoflagellates. J Eukaryot Microbiol 46:397-401

Stoecker DK, Michaels AE (1991) Respiration, photosynthesis and carbon metabolism in planktonic ciliates. Mar Biol 108:441-447

Stoecker DK, Silver MW (1990) Replacement and aging of chloroplasts in Strombidium capitatum (Ciliophora, Oligotrichida). Mar Biol 107:491-502

Stoecker DK, Michaels AE, Davis LH (1987) Large proportion of marine planktonic ciliates found to contain functional chloroplasts. Nature 326:790-792

Stoecker DK, Silver MW, Michaels AE, Davis LH (1988) Obligate mixotrophy in Laboea strobila, a ciliate which retains chloroplasts. Mar Biol 99:415-423

Stoecker DK, Sliver MW, Michaels AE, Davis LH (1988-1989) Enslavement of algal chloroplasts by 4 Strombidium spp. (Ciliophora, Oligotrichida). Mar Microb Food Webs 3: 79-100

- Stoecker DK, Taniguchi A, Michaels AE (1989) Abundance of autotrophic, mixotrophic and heterotrophic planktonic ciliates in shelf and slope waters. Mar Ecol Prog Ser 50: 241-254

> Stoecker DK, Putt M, Davis LH, Michaels AE (1991) Photosynthesis in Mesodinium rubrum: species-specific measure- ments and comparison to community rates. Mar Ecol Prog Ser 73:245-252

Stoecker DK, Sieracki ME, Verity PG, Michaels AE, Haugen E, Burkill PH, Edwards ES (1994) Nanoplankton and protozoan microzooplankton during the JGOFS North Atlantic Bloom Experiment: 1989 and 1990. J Mar Biol Assoc UK 74:427-443

Stoecker DK, Putt M, Moisan T (1995) Nano- and microplankton dynamics during the spring Phaeocystis sp. bloom in McMurdo Sound, Antarctica. J Mar Biol Assoc UK 75: 815-832

Stoecker DK, Gustafson DE, Verity PG (1996) Micro- and mesoprotozooplankton at $140^{\circ} \mathrm{W}$ in the equatorial Pacific: heterotrophs and mixotrophs. Aquat Microb Ecol 10: 273-282

Straile D (1997) Gross growth efficiencies of protozoan and metazoan zooplankton and their dependence on food concentration, predator-prey weight ratio, and taxonomic group. Limnol Oceanogr 42:1375-1385

Strom SL (2008) Microbial ecology of ocean biogeochemistry: a community perspective. Science 320:1043-1045

Summerer M, Sonntag B, Sommaruga R (2008) Ciliate-symbiont specificity of freshwater endosymbiotic Chlorella (Trebouxiophyceae, Chlorophyta). J Phycol 44:77-84

Suzuki T, Taniguchi A (1998) Standing crops and vertical distribution of four groups of marine planktonic ciliates in relation to phytoplankton chlorophyll a. Mar Biol 132: $375-382$

Swanberg NR (1983) The trophic role of colonial radiolaria in oligotrophic oceanic environments. Limnol Oceanogr 28: $655-666$

Sweeney BM (1978) Ultrastructure of Noctiluca millaris (Pyrrophyta) with green flagellate symbionts. J Phycol 14:116-120

Tagle HK, Williams DE, Hallock P, Harney JN (1997) Symbiont loss in reef foraminifera: consequences for affected populations. In: Lessios HA, Macintyre IG (eds) Proc 8th Int Coral Reef Symp, Panama, p 589-594

Takahashi K, Bé AWH (1984) Planktonic foraminifera: factors controlling sinking speeds. Deep-Sea Res I 31: $1477-1500$

Takishita K, Koike K, Maruyama T, Ogata T (2002) Molecular evidence for plastid robbery (Kleptoplastidy) in Dinophysis, a dinoflagellate causing diarrhetic shellfish poisoning. Protist 153:293-302

Tamura M, Shimada S, Horiguchi T (2005) Galeidiniium rugatum gen. et sp nov (Dinophyceae), a new coccoid dinoflagellate with a diatom endosymbiont. J Phycol 41:658-671

Tanaka S, Takahashi K (2008) Detailed vertical distribution of radiolarian assemblage $(0-3000 \mathrm{~m}$, fifteen layers $)$ in the central subarctic Pacific, June 2006. Memoirs of the Faculty of Sciences, Kyushu University, Series D. Earth Planetary Sci 32:49-72

Taylor FJR (1982) Symbioses in marine microplankton. Ann Inst Oceanogr Paris 58(S):61-90

Taylor FJR (1990) Symbiosis in marine protozoa. In: Capriulo GM (ed) The ecology of marine protozoa. Oxford University Press, New York, p 323-340

Taylor FJR, Blackbourn DJ, Blackbourn J (1969) Ultrastructure of the chloroplasts and associated structures within the marine ciliate Mesodinium rubrum (Lohmann). Nature 224:819-821

Taylor FJR, Blackbourn DJ, Blackbourn J (1971) Red-water ciliate Mesodinium rubrum and its 'incomplete symbionts': a review including new ultrastructural observations. J Fish Res Board Can 28:391-407 
ter Kuile B, Erez J (1987) Uptake of inorganic carbon and internal cycling in symbiont-bearing foraminifera. Mar Biol 94:499-510

Thompson PR, Bé AWH, Duplessy JC, Shackleton NJ (1979) Disappearance of pint-pigmented Globigerinoides ruber at 120,000 yr BP in the Indian and Pacific Oceans. Nature 280:554-557

Thouvenot A, Richardot M, Debroas D, Devaux J (1999) Bacterivory of metazooplankton, ciliates and flagellates in a newly flooded reservoir. J Plankton Res 21:1659-1679

Tomas RN, Cox ER (1973) Observations on the symbiosis of Peridinium balticum and its intracellular algae. I. Ultrastructure. J Phycol 9:304-323

Tonooka Y, Watanabe T (2002) A natural strain of Paramecium bursaria lacking symbiotic algae. Eur J Protistol 38:55-58

Tregouboff G (1953) Classe des Acanthaires. In: Grassé PP (ed) Traité de zoologie, Vol 1. Masson, Paris, p 271-320

Vaqué D, Blough HA, Duarte CM (1997) Dynamics of ciliate abundance, biomass and community composition in an oligotrophic coastal environment (NW Mediterranean). Aquat Microb Ecol 12:71-83

Verity PG, Vernet M (1992) Microzooplankton grazing, pigments, and composition of plankton communities during late Spring in two Norwegian fjords. Sarsia 77:263-274

Vershinin A, Moruchkov A, Morton SL, Leighfield TA, Quilliam MA, Ramsdell JS (2006) Phytoplankton composition of the Kandalaksha Gulf, Russian White Sea: Dinophysis and lipophilic toxins in the blue mussel (Mytilus edulis). Harmful Algae 5:558-564

Vogelbein WK, Lovko VJ, Shields JD, Reece KS, Mason PL, Haas LW, Walker CC (2002) Pfiesteria shumwayae kills

Submitted: April 29, 2009; Accepted: June 10, 2009 fish by micropredation not exotoxin secretion. Nature 418:967-970

Wilcox LW, Wedemayer GJ (1985) Dinoflagellate with bluegreen chloroplasts derived from an endosymbiotic eukaryote. Science 227:192-194

Witek M (1998) Annual changes of abundance and biomass of planktonic ciliates in the Gdańsk Basin, southern Baltic. Int Rev Hydrobiol 83:163-182

Woelfl S, Geller W (2002) Chlorella-bearing ciliates dominate in an oligotrophic North Patagonian lake (Lake Pirehueico, Chile): abundance, biomass and symbiotic photosynthesis. Freshw Biol 47:231-242

> Yih W, Kim HS, Jeong HJ, Myung G, Kim YG (2004) Ingestion of cryptophyte cells by the marine photosynthetic ciliate Mesodinium rubrum. Aquat Microb Ecol 36:165-170

Zettler LA, Anderson OR, Caron DA (1998) Insights on the diversity within a 'species' of Thalasicolla (Spumellarida) based on 16S-like ribosomal RNA gene sequencing. J Eukaryot Microbiol 45:488-496

Zhang W, Xu K, Wan R, Zhang G and others (2002) Spatial distribution of ciliates, copepod nauplii and eggs, Engraulis japonicus post-larvae and microzooplankton herbivorous activity in the Yellow Sea, China. Aquat Microb Ecol 27:249-259

Zingel P, Ott I (2000) Vertical distribution of planktonic ciliates in strongly stratified temperate lakes. Hydrobiologia 435:19-26

Żmijewska MI, Niemkiewicz E, Bielecka L (2000) Abundance and species composition of plankton in the Gulf of Gdańsk near the planned underwater outfall of the GdańskWschód ( Gdańsk-East) sewage treatment plant. Oceanologia 42:335-357

Proofs received from author(s): November 11, 2009 